\title{
Contributions from glacially derived sediment to the global iron (oxyhydr)oxide cycle: Implications for iron delivery to the oceans
}

\author{
Rob Raiswell ${ }^{\mathrm{a}, *}$, Martyn Tranter ${ }^{\mathrm{b}}$, Liane G. Benning ${ }^{\mathrm{a}}$, Martin Siegert ${ }^{\mathrm{b}}$, Ros De'ath ${ }^{\mathrm{b}}$, \\ Philippe Huybrechts ${ }^{\mathrm{c}}$, Tony Payne ${ }^{\mathrm{b}}$ \\ ${ }^{\text {a }}$ School of Earth and Environment, University of Leeds, Leeds LS2 9JT, UK \\ ${ }^{\mathrm{b}}$ Bristol Glaciology Centre, School of Geographical Sciences, University of Bristol, Bristol BS8 1SS, UK \\ ' Vrije Universiteit Brussel, Department Geografie, Pleinlaan 2, B-1050 Brussels, Belgium
}

Received 26 July 2005; accepted in revised form 30 December 2005

\begin{abstract}
Estimates of glacial sediment delivery to the oceans have been derived from fluxes of meltwater runoff and iceberg calving, and their sediment loads. The combined total $\left(2900 \mathrm{Tg} \mathrm{yr}^{-1}\right)$ of the suspended sediment load in meltwaters $\left(1400 \mathrm{Tg} \mathrm{yr}^{-1}\right)$ and the sediment delivered by icebergs $\left(1500 \mathrm{Tg} \mathrm{yr}^{-1}\right)$ are within the range of earlier estimates. High-resolution microscopic observations show that suspended sediments from glacial meltwaters, supraglacial, and proglacial sediments, and sediments in basal ice, from Arctic, Alpine, and Antarctic locations all contain iron (oxyhydr)oxide nanoparticles, which are poorly crystalline, typically $\sim 5 \mathrm{~nm}$ in diameter, and which occur as single grains or aggregates that may be isolated or attached to sediment grains. Nanoparticles with these characteristics are potentially bioavailable. A global model comparing the sources and sinks of iron present as (oxyhydr)oxides indicates that sediment delivered by icebergs is a significant source of iron to the open oceans, beyond the continental shelf. Iceberg delivery of sediment containing iron as (oxyhydr)oxides during the Last Glacial Maximum may have been sufficient to fertilise the increase in oceanic productivity required to drawdown atmospheric $\mathrm{CO}_{2}$ to the levels observed in ice cores.
\end{abstract}

(C) 2006 Elsevier Inc. All rights reserved.

\section{Introduction}

Rates of sediment delivery to ocean basins are difficult to quantify, whether by riverine, glacial or aeolian supply. There are two principal sources of uncertainty. The first arises from the spatial and temporal variability of clastic fluxes, which requires frequent sampling over prolonged intervals and at many geographically diverse locations. The second arises from the fact that sediment fluxes can be altered during transfer from their reservoir of origin into the ocean basins. For example, riverine clastic loads are frequently measured at upstream sites, below which there may be substantial amounts of sediment storage on a temporary or permanent basis (Hay, 1998). Furthermore,

\footnotetext{
${ }^{*}$ Corresponding author. Fax: +441133435259.

E-mail address: r.raiswell@earth.leeds.ac.uk (R. Raiswell).
}

riverine transport through estuaries may be non-conservative and may alter the relative proportions of various sediment components (see below). As a result, the particulate loads delivered into the ocean basins (e.g., Duce et al., 1991; Milliman and Syvitski, 1992; Hay, 1998; Poulton and Raiswell, 2002) are much less accurately quantified than solute loads, despite being important to a detailed understanding of biogeochemical cycles (such as the iron cycle), that are dominated by clastic rather than dissolved fluxes.

Current interest in the iron cycle derives from the observation that phytoplankton production in major ocean regions appears to be linked to iron availability. The main forms of iron that are, directly or indirectly, bioavailable appear to be dissolved monomeric hydrolysed species or organic chelates (Sunda, 2001). However, measurements of dissolved $\mathrm{Fe}$ are typically made on samples which have passed through membrane filters with a nominal cut off 
of $0.2-0.4 \mu \mathrm{m}$, which includes the above species plus larger colloidal material. We shall follow convention in defining this filterable fraction as dissolved whilst noting that the extent to which the colloid material is bioavailable in seawater, or could dissolve to produce hydrolysed or chelated species, may be significant but is unknown (de Baar and de Jong, 2001). Overall, the colloidal fraction is defined as single or aggregated particles, usually having sizes below $1 \mu \mathrm{m}$, which are mostly trapped by conventional filtration. However, the smaller fraction (usually nanoparticulates $<100 \mathrm{~nm}$ ) is ill defined and generally included in the dissolved fraction.

The dissolved riverine load of iron is small ( $1 \pm 1 \mathrm{Tg} \mathrm{yr}^{-1}$; de Baar and de Jong, 2001; Poulton and Raiswell, 2002) and the flux into the oceans is further decreased (to approximately $10 \%$ or $0.1 \pm 0.1 \mathrm{Tg} \mathrm{yr}^{-1}$ ) by removal in estuaries (e.g., Holliday and Liss, 1976; Sholkovitz, 1976; Boyle et al., 1977; Wu and Luther, 1996). Most of this removal is accounted for by loss of the colloidal fraction by aggregation and deposition (Wen et al., 1999). Truly dissolved $\mathrm{Fe}$ concentrations also appear to decrease during estuarine transport but only as a result of dilution with seawater (Dai and Martin, 1995). The residual, dissolved riverine supply to the oceans mainly supports near-shore biological activity, probably augmented by fluxes derived from resuspended shelf sediments (Hutchins et al., 1998; Johnson et al., 1999) and diagenetic recycling (Elrod et al., 2004; Raiswell and Anderson, 2005). Thus, alternative sources of dissolved $\mathrm{Fe}$ are required to fertilise the oceans beyond the continental shelf.

The riverine supply of dissolved iron to the oceans is nearly 3 orders of magnitude lower than the supply of particulate $\mathrm{Fe}$ as (oxyhydr)oxides (ferrihydrite, lepidocrocite, goethite, and hematite) by rivers, glaciers, and aeolian dust (Poulton and Raiswell, 2002). Hence processes that can derive even small amounts of iron from the less refractory fractions of these solid phases may be important in maintaining steady state levels of bioavailable iron (Moffett, 2001). The fine-grained aluminosilicate fraction of aeolian dust is considered to be an important source of dissolved Fe to the open oceans via both wet and dry deposition, supplying approximately $14-35 \mathrm{Tg} \mathrm{yr}^{-1}$ of total Fe (Jickells and Spokes, 2001). Material supplied by dry deposition is considered essentially insoluble in seawater, but cycling within low $\mathrm{pH}$ cloud droplets is believed to modify the wet deposition such that approximately $1-5 \%$ of the total $\mathrm{Fe}$ (0.2-2 $\mathrm{Tg} \mathrm{yr}^{-1}$; de Baar and de Jong, 2001; Jickells and Spokes, 2001) contributes to the pool of dissolved Fe in seawater.

Studies of glacial and sea-ice sources of Fe to the oceans have principally focused on the supply of dissolved Fe released by melting. They indicate that ice contains concentrations of $\mathrm{Fe}$ in the range of $10-50 \mathrm{nM}$ (de Baar et al., 1990; Martin et al., 1990; Loscher et al., 1997). Thus, the dissolved $\mathrm{Fe}$ concentrations of surface waters in the wake of melting icebergs in the Polar Frontal region of Antarctica (1-9 nM) appear to be enhanced over local seawater concentrations $(1-2 \mathrm{nM})$. This ice-derived dissolved $\mathrm{Fe}$ is believed to originate either from aeolian dust or from sea-ice formed in coastal waters with relatively high dissolved Fe concentrations (de Baar and de Jong, 2001). However, icebergs also contain comminuted continental debris, particularly in basal layers, and may accumulate additional sediment during passage over the continental shelves (de Baar and de Jong, 2001). These sediments may already contain nanoparticulate iron (oxyhydr)oxides derived from the weathering of reactive iron-bearing phases (e.g. sulfides, carbonates, olivines, and pyroxenes) where contact with meltwaters has been possible before their final freezing into ice. Aging of these (oxyhydr)oxides is minimised by their transport to the oceans in a frozen matrix. However, fresh iron (oxyhydr)oxides may also be produced as the sediment contained in icebergs is released and weathered during melting. Direct delivery into the oceans avoids the aggregation and deposition that occurs during estuarine transport.

Culture studies with marine diatoms (Wells et al., 1983; Rich and Morel, 1990) have shown that freshly prepared poorly ordered $\mathrm{Fe}(\mathrm{III})$ (oxyhydr)oxides (primarily ferrihydrite) can supply iron for cell growth, but this is not true for more crystalline phases (akaganeite, goethite, and hematite). Wells et al. (1983) suggest the bioavailability of $\mathrm{Fe}$ from iron (oxyhydr)oxides decreases with increasing thermodynamic stability of the solid phase. Thus, the bioavailability of $\mathrm{Fe}$ decreases with increasing crystallinity and with the loss of water that occurs when poorly ordered (oxyhydr)oxides (i.e., 2- and 6-line ferrihydrite) age to their more crystalline and stable counterparts (lepidocrocite, hematite or goethite; Schwertmann and Taylor, 1972; Schwertmann and Fischer, 1973; Cornell and Schwertmann, 2003). Aging and crystallisation can occur both in oxic environments and in anoxic media (Shaw et al., 2005; Yee et al., 2006). An additional factor that requires consideration is irradiation. Wells and Mayer (1991) found that the bioavailability of $\mathrm{Fe}$ from both crystalline and non-crystalline iron (oxyhydr)oxides in seawater could be increased by irradiating with UV light, and simulated or natural sunlight. Johnson et al. (1994) and Barbeau and Moffett (2000) also found evidence for the photochemical dissolution of colloidal iron (but see Miller et al., 1995).

Transmission electron microscopy (TEM) studies (Poulton and Raiswell, 2005) have shown that a significant proportion of the (oxyhydr)oxide iron in riverine suspended sediment exists as nanoparticles (10-20 nm diameter). The solubilities of iron (oxyhydr)oxides vary with surface area, crystallinity, and impurity content (Bonneville et al., 2004) and nanoparticles with diameters $\sim 10 \mathrm{~nm}$ may have solubilities that are increased by approximately two orders of magnitude (e.g., Banfield and Zhang, 2001; Cornell and Schwertmann, 2003). It follows that the presence of nanoparticulate iron (oxyhydr)oxides in the glacially derived clastic flux may constitute a source of bioavailable iron to the oceans. 
Glaciers are renowned as agents of physical erosion. The ratio of physical to chemical erosion is approximately an order of magnitude higher in glacial environments than in non-glacial environments. Typically, glacial runoff contains $\sim 1.0 \mathrm{~kg} \mathrm{~m}^{-3}$ of suspended sediment (see later and Gurnell, 1987), whereas runoff from non-glaciated terrain contains $\sim 0.5 \mathrm{~kg} \mathrm{~m}^{-3}$ (Holland, 1978). By contrast, glacial runoff contains $\sim 15 \mathrm{~g} \mathrm{~m}^{-3}$ of crustally derived solute (after Tranter et al., 2002), whereas runoff from non-glaciated terrain contains $\sim 75 \mathrm{~g} \mathrm{~m}^{-3}$ (Holland, 1978). Hence, the ratio of physical to chemical erosion is $\sim 70$ in glaciated terrain, in comparison to $\sim 7$ in non-glaciated terrain. The plentiful supply of sediments by glacial erosion enables glacial meltwaters to carry particularly high loads of both suspended and bed load sediments (Gurnell, 1987). There are a wide range of estimates of the quantity of glacial sediment transferred into the ocean basins (see below), with values in the range of $\sim 5-20 \%$ of riverine sediment loads. To date, no study has been undertaken of the potential bioavailability of $\mathrm{Fe}$ from glacial sediments. This paper attempts to redress this gap in the literature. Specifically, the aims of this paper are first, to estimate the glacial sediment flux to the oceans, partitioning the flux into that derived from smaller and larger ice masses, and that derived from runoff and icebergs. These factors influence the locus of sediment delivery to the oceans (see below). The second aim is to characterise the physical properties of glacially derived iron (oxyhydr)oxides in order to assess their potential bioavailability. Finally, the third aim is to construct a global cycle of iron (oxyhydr)oxides in order to identify the importance of glacial supply relative to the other major sources and sinks.

\section{Methods}

A variety of different types of sediment (Table 1) were collected from Alpine, Arctic, and Antarctic glaciers. Samples collected in the European Alps include subglacial sediments collected from a cavity below the Glacier d'Argentiere (Souchez et al., 1973), suspended sediments originating from the Saint-Sorlin Glacier, and proglacial plain sediments from Les Bossons. One Arctic sample was collected from the Finsterwalderbreen, Svalbard. Suspended sediments were filtered $(0.45 \mu \mathrm{m})$ in the field from meltwaters close to the glacier snout. Further details of these samples are given in Poulton and Raiswell (2005). Samples from Antarctica included sediment from basal ice in the Campbell Glacier (Victoria Land), and supraglacial sediments from the Canada Glacier (Dry Valleys) and the Crary Ice Rise (Ross Ice Shelf). Proglacial plain sediments were collected from Orwell Glacier, Signy Island in the Maritime Antarctic. Fine grain fractions $(<2 \mathrm{~m}$ and $<6 \mu \mathrm{m})$ were separated by density separation in water according to Stoke's law.

The sediments were subjected to an extraction procedure (Raiswell et al., 1994; Raiswell and Canfield, 1998; Poulton and Canfield, 2005) that solubilises poorly ordered and crystalline iron (oxyhydr)oxides (with the exception of magnetite) using a buffered sodium dithionite solution $(\mathrm{pH} 4.8)$ for $2 \mathrm{~h}$. This iron fraction is considered to be highly reactive (compared to other non-oxide or silicate minerals) and is termed $\mathrm{Fe}_{\mathrm{HR}}$. A $\mathrm{HF}-\mathrm{HClO}_{4}-\mathrm{HNO}_{3}$ technique was used to extract total $\mathrm{Fe}(\mathrm{FeT})$. Iron measurements were by flame AAS. Replicate extractions $(n=8)$ of stream sediment standard STSD-1 indicate a precision of $<4 \%$ for all methods, and total iron measurements were within $2 \%$ of the certified value (Poulton and Raiswell, 2002). Analytical data are summarised in Table 1.

The mineralogy of the samples (Table 1) was determined with a Philips PW1050 X-ray diffraction Goniometer using a $\mathrm{Cu} \mathrm{K} \alpha$ radiation X-ray tube and the ICDD PDF2 (International Centre for Diffraction Data Powder Diffraction Files) database. The morphology and distribution of phases, and a qualitative elemental analysis of the samples, was obtained using a LEO 1530 Field-Emission Gun Scanning Electron Microscope (FEG-SEM) with an attached EDS system. Samples were suspended in ethanol and dispersed using ultrasonic methods and then deposited on Al-stubs. These were coated with $3 \mathrm{~nm}$ Platinum and imaged at an accelerating voltage of $3 \mathrm{kV}$ and a working distance of

Table 1

Glacial sediment samples

\begin{tabular}{|c|c|c|c|c|c|c|}
\hline Sample & Location & Sediment type and mineralogy & Main bedrock lithologies & $\% \mathrm{Fe}_{\mathrm{HR}}$ & $\% \mathrm{FeT}$ & $\mathrm{Fe}_{\mathrm{HR}} / \mathrm{FeT}$ \\
\hline Finsterwalderbreen $<2 \mu \mathrm{m}$ & Svalbard & Suspended Q, C, F, K, M & $\begin{array}{l}\text { Schists, siltstones, } \\
\text { sandstones, shales }\end{array}$ & 5.51 & 7.86 & 0.70 \\
\hline Saint Sorlin $<2 \mu \mathrm{m}$ & Alps, France & Suspended Q, C, F, M & $\begin{array}{l}\text { Dolomites, shales, } \\
\text { schists, volcanics }\end{array}$ & 1.88 & 8.08 & 0.23 \\
\hline Argentiere $<2 \mu \mathrm{m}$ & Alps, France & Subglacial Q, C, Ca, F, M & Granite, gneiss & 0.25 & 2.82 & 0.09 \\
\hline Les Bossons $<6 \mu \mathrm{m}$ & Alps, France & Proglacial Q, C, F, M & Granite, gneiss & 1.75 & 7.57 & 0.23 \\
\hline Campbell Glacier $<6 \mu \mathrm{m}$ & Victoria Land, Antarctica & Basal ice $\mathrm{Q}, \mathrm{C}, \mathrm{F}, \mathrm{M}$ & $\begin{array}{l}\text { Metasediments } \\
\text { (shales, carbonates, sands) }\end{array}$ & 0.99 & 5.52 & 0.18 \\
\hline Crary Ice Rise $<6 \mu \mathrm{m}$ & Ross Ice Shelf, Antarctica & Supraglacial Q, C, F, M & Basaltic volcanics & 0.46 & 4.56 & 0.10 \\
\hline Orwell Glacier $<6 \mu \mathrm{m}$ & Signy Island, Antarctica & Proglacial Q, C, I, K & $\begin{array}{l}\text { Metasediments } \\
\text { (shales, sands, carbonates), } \\
\text { ultrabasics }\end{array}$ & 4.68 & 8.96 & 0.52 \\
\hline Canada Glacier $<6 \mu \mathrm{m}$ & Dry Valleys, Antarctica & Supraglacial Q, C, F, M & Granite, dolerite, sandstone & 2.39 & 8.29 & 0.29 \\
\hline
\end{tabular}

Mineralogy: Q, quartz; C, chlorite; Ca, calcite; F, feldspar; I, illite; K, kaolinite; M, muscovite. 
3-5 mm. For the high-resolution work, a Philips CM200 Field-Emission Gun-Transmission Electron Microscope (FEG-TEM) was used. The FEG-TEM system was operated at $197 \mathrm{keV}$ and was equipped with a Supertwin Objective lens, an Oxford Instrument UTW Energy Dispersive $\mathrm{X}$-ray spectrometer (EDS) and a Gatan Imaging Filter for Electron Energy Loss Spectroscopy (EELS). The powdered samples were suspended in ethanol, ultrasonicated for $10 \mathrm{~min}$, deposited on standard holey carbon support films on copper grids (Agar Scientific Ltd.) and after drying imaged directly with no thinning. EDS point spectra, dark field images, and EELS elemental maps were acquired on selected spots and areas that were selected and identified based on equivalent FEG-SEM analyses of the same sample.

\section{Estimation of the glacially derived sediment flux}

\subsection{Previous approaches}

Previous estimates of the global glacial sediment flux have been reviewed by Hay (1998) and are based either on estimates of sediment yields (mass per unit area per unit time) from glaciated basins, or on estimates of masses of sediment per unit volume (of ice or water) and the mass flux of ice or water. The first approach was used by Garrels and Mackenzie (1971), who estimated that about $0.69 \mathrm{~km}^{3}$ of chemically unweathered, fine-grained rock material was eroded annually from Antarctica, giving a sediment yield of $0.14 \mathrm{~kg} \mathrm{~m}^{-2} \mathrm{yr}^{-1}$ from an area of $13 \times 10^{12} \mathrm{~m}^{2}$. It was assumed that Antarctica supplied $90 \%$ of the global glacial sediment flux, which was thus estimated as approximately $2000 \mathrm{Tg} \mathrm{yr}^{-1}$. Hallet et al. (1996) showed that erosion rates were lowest for polar glaciers and plateau glaciers on crystalline rocks, but significantly higher for temperate valley glaciers on crystalline bedrock, and higher still for temperate valley glaciers on other, non-crystalline, rock types. Based on these data, Hay (1998) suggested that Antarctica (area $\left.13 \times 10^{6} \mathrm{~km}^{2}\right)$ and Greenland $\left(2.2 \times 10^{6} \mathrm{~km}^{2}\right)$ would behave as polar glaciers with sediment yields of approximately $5 \times 10^{-4} \mathrm{~kg} \mathrm{~m}^{-2} \mathrm{yr}^{-1}$ and thus would contribute a total sediment flux of $7 \mathrm{Tg} \mathrm{yr}^{-1}$. The vastly smaller area of the remaining glaciated regions $\left(0.8 \times 10^{6} \mathrm{~km}^{2}\right)$ were assumed to have yields equivalent to the mean for temperate glaciers $\left(1 \mathrm{~kg} \mathrm{~m}^{-2} \mathrm{yr}^{-1}\right)$, and hence produced a substantially higher sediment flux of $800 \mathrm{Tg} \mathrm{yr}^{-1}$. Hence Hay (1998) produced a best estimate of $800 \mathrm{Tg} \mathrm{yr}^{-1}$ (and an estimated range of $800-5000 \mathrm{Tg} \mathrm{yr}^{-1}$ ) for the global glacial flux, whilst observing that this best estimate should be revised as new data from Antarctica and Greenland became available. Clearly, there is a significant difference between the estimates of Garrels and Mackenzie (1971) and Hay (1998) in respect of the relative importance of polar versus temperate glacial fluxes. One important element that may lead to the underestimation of sediment fluxes from Antarctica is that of catchment area. Hallet et al. (1996) demonstrate that specific sediment yield increases with the area of the glaciated catchment. Hence, larger catchments in Antarctica, particularly those with fast ice streams, may deliver more sediment than estimates based on sediment yields in smaller catchments.

The second approach was used by Lisitzin (1972) who estimated a substantially larger sediment flux $(35,000$ $50,000 \mathrm{Tg} \mathrm{yr}^{-1}$ ) by assuming that Antarctica produced an annual ice flux of $1000-1500 \mathrm{~km}^{3}$ with a mean sediment content of $1.6 \%$ by volume (or $\sim 43 \mathrm{~kg} \mathrm{~m}^{-3}$ ). Recent data (see below) suggest that sediment contents as high $43 \mathrm{~kg} \mathrm{~m}^{-3}$ of ice are only found in the debris-rich layers of ice-bergs but are unlikely to be found in cleaner, nonbasal ice.

\subsection{Estimation of glacial fluxes}

The current estimated glacial meltwater runoff from the Antarctic and Greenland ice sheets (Table 2) is 0.01 and $\sim 0.3 \mathrm{Tm}^{3} \mathrm{yr}^{-1}$, respectively (Church et al., 2001). Glacial runoff from smaller ice masses and glaciers is harder to establish but, if it is assumed that the volume of these smaller ice masses is $\sim 180 \mathrm{Tm}^{3}$ (Church et al., 2001), that the principal mass loss is via runoff and that the average residence time of ice in the smaller ice masses is 100 years (Warrick and Oerlemans, 1990), then glacial runoff from smaller ice masses is $\sim 1.8 \mathrm{Tm}^{3} \mathrm{yr}^{-1}$ (Tranter, 2005). This figure should be reduced by $\sim 0.7 \mathrm{Tm}^{3} \mathrm{yr}^{-1}$ to account for the mass lost as icebergs (Lisitzin, 2002), to give a value of $\sim 1.1 \mathrm{Tm}^{3} \mathrm{yr}^{-1}$ for the meltwater discharge. This is about 3-4 times greater than current meltwater discharge from ice

Table 2

Glacial meltwater and sediment fluxes

\begin{tabular}{|c|c|c|c|c|c|}
\hline Mass flux & $\begin{array}{l}\text { Sediment } \\
\text { conc. }\left(\mathrm{kg} \mathrm{m}^{-3}\right)\end{array}$ & $\begin{array}{l}\text { Current ice/water } \\
\text { discharge }\left(\operatorname{Tm}^{3} \mathrm{yr}^{-1}\right)\end{array}$ & $\begin{array}{l}\text { Current sediment } \\
\text { flux }\left(\mathrm{Tg} \mathrm{yr}^{-1}\right)\end{array}$ & $\begin{array}{l}\text { Ice/water discharge at } \\
\text { the LGM }\left(\mathrm{Tm}^{3} \mathrm{yr}^{-1}\right)\end{array}$ & $\begin{array}{l}\text { Sediment flux at } \\
\text { LGM }\left(\operatorname{Tg~yr}^{-1}\right)\end{array}$ \\
\hline Meltwater from ice sheets & 1 & 0.3 & 300 & $1-2$ & $1000-2000$ \\
\hline Meltwater from smaller ice masses & 1 & 1.1 & 1100 & $3-6$ & $3000-6000$ \\
\hline Total sediment flux to water $<1 \mathrm{~km}$ depth & & & 1400 & & $4000-8000$ \\
\hline Iceberg calving from ice sheets & 0.5 & 2.2 & 1100 & 6 & 3000 \\
\hline Iceberg calving from smaller ice masses & 0.5 & 0.7 & 350 & $3-6$ & $1500-3000$ \\
\hline
\end{tabular}


sheets. Hence, present day global glacial meltwater discharge is $\sim 1.4 \mathrm{Tm}^{3} \mathrm{yr}^{-1}$ (Table 2)

An estimate of the suspended load of glacial runoff can be extracted from the data of Gurnell (1987) for 43 glaciated mountain, sub-arctic mountain and arctic catchments. These data demonstrate a close relationship between sediment yield and discharge that indicates an approximate mean suspended sediment load of $1 \mathrm{~kg} \mathrm{~m}^{-3}$. Given that the glacial meltwater discharge is $\sim 1.4 \mathrm{Tm}^{3} \mathrm{yr}^{-1}$, then the global glacial suspended sediment flux is $\sim 1400 \mathrm{Tg} \mathrm{yr}^{-1}$ (Table 2). The shortcomings of this estimate include the deposition and temporary storage of suspended sediment in terrestrial environments (Sugden and John, 1976), and the potential for double counting suspended sediment of glacial origin as riverine, particularly in Asia where glaciated headwater catchments may be several hundred kilometers from the coast. The latter error is of little importance in the context of iron (oxyhydr)oxide delivery to the oceans because most colloidal iron (hydr)oxides are removed during passage through estuaries (see later).

Meltwater is often a major loss of mass for smaller glaciers and ice caps, but iceberg calving is often the major mass loss term from ice sheets (Paterson, 1994). Calving icebergs carry significant quantities of sediment, particularly in the lower meters of ice (Dowdeswell and Murray, 1990). Hence some estimate of iceberg sediment fluxes is necessary to fully quantify glacial sediment fluxes to the oceans (Lisitzin, 1972). Current estimates of iceberg calving from Greenland and Antarctica are $\sim 0.2$ and $\sim 2 \mathrm{Tm}^{3} \mathrm{yr}^{-1}$ water equivalent, respectively (Church et al., 2001), and smaller ice masses may also contribute up to $0.7 \mathrm{Tm}^{3} \mathrm{yr}^{-1}$ (Lisitzin, 2002), giving a combined iceberg flux of $\sim 2.9 \mathrm{Tm}^{3} \mathrm{yr}^{-1}$ water equivalent (Table 2). This is approximately double our estimate of the global meltwater flux. The sediment content of icebergs is poorly known, but Dowdeswell and Dowdeswell (1989) report sediment concentrations of $0.2-200 \mathrm{~kg} \mathrm{~m}^{-3}$ for icebergs from Svalbard, with the higher concentrations $\left(>30 \mathrm{~kg} \mathrm{~m}^{-3}\right)$ found in debris-rich basal layers. Overall, a typical value for the sediment content of icebergs is believed to be $\sim 0.5 \mathrm{~kg} \mathrm{~m}^{-3}$ (De'ath, 2004), similar to that of river water. Hence, the flux of glacial sediment transported into the oceans by icebergs is $\sim 1500 \mathrm{Tg} \mathrm{yr}^{-1}$ (Table 2). This value is similar to the above estimate of the meltwater suspended sediment flux. We have ignored the cyclical effects of freezing and melting of basal ice in coastal waters, particularly around Antarctica, since the quantitative effect on basal ice contents is unknown at present. In total, the potential flux of glacial sediment to the oceans is approximately $2900 \mathrm{Tg} \mathrm{yr}^{-1}$.

The debris content of non-basal or meteoric ice in the Antarctic and Greenland Ice Sheets is of the order of $0.2-2 \mathrm{~g} \mathrm{~m}^{-3}$ (Paterson, 1994; Wilson et al., 2000). Relatively low concentrations are found in studies of aerosols in Holocene ice but higher aerosol concentrations occurred at the Last Glacial Maxima (e.g., Petit et al., 1981; Angelis et al., 1987). Most of the debris in meteoric or non-basal ice is of aerosol origin (i.e., that both wet deposited in snow and dry deposited onto the glacier surface). Thus, the maximum mass flux of aerosol dust attributable to melting icebergs is $\sim 6 \mathrm{Tg} \mathrm{yr}^{-1}$.

The total estimate of glacial sediment transport to the oceans in Table 2 is approximately $50 \%$ higher than that of Garrels and Mackenzie (1971). This is largely because we have assumed that all glacial suspended sediment $(\sim 50 \%$ of our total glacial sediment flux) reaches the oceans, rather than is deposited on land. Our estimate is an order of magnitude lower than that of Lisitzin (1972), mainly because of our lower estimate of the debris content of icebergs $\left(\sim 40 \mathrm{~kg} \mathrm{~m}^{-3}\right.$ cf. $\left.\sim 0.5 \mathrm{~kg} \mathrm{~m}^{-3}\right)$. The value reported by Lisitzin (1972) can be found in the debris-rich basal layers of icebergs (Dowdeswell and Dowdeswell, 1989), but is unlikely to be found in cleaner, non-basal ice. Our estimate is higher than the best estimate of Hay (1998), principally because we assume that icebergs transport more sediment from Antarctica.

Crudely, we assume that suspended sediment in meltwater runoff is deposited in water depths of $<1 \mathrm{~km}$ and that icebergs deposit sediment in waters $>1 \mathrm{~km}$ deep. This is a gross simplification, and does not acknowledge the multiple processes that occur in coastal environments receiving inputs from either glacial meltwaters and/or icebergs (Syvitski et al., 1987; Dowdeswell and Scourse, 1990; Lisitzin, 2002). Better quantitative depositional models than are presently available are required to improve the partition of glaciomarine sediments between slope and shelf environments.

\section{Nanoparticulate morphologies and surface interactions}

\subsection{Previous observations}

Numerous studies (Whitney, 1975; Horowitz and Elrick, 1987; Turner et al., 1991; Hedges and Keil, 1995; Brown et al., 1999; Kaiser and Guggenberger, 2000; Cornell and Schwertmann, 2003; Poulton and Raiswell, 2005) have identified close correlations between iron (oxyhydr)oxide content and surface area in freshwater and marine sediments. However, the existence of (oxyhydr)oxides as continuous monolayer coatings has never been demonstrated in natural systems. Furthermore, loadings of iron on shelf sediments and riverine suspended sediments are sufficiently small $\left(0.2-2.0 \mathrm{mg} \mathrm{Fe} \mathrm{m}^{-2}\right.$; Hedges and Keil, 1995; Poulton and Raiswell, 2005) that any continuous layer would have to be $<1 \mathrm{~nm}$ in thickness and hence beyond the resolution of conventional electron microscopy (see analogous discussion of organic $\mathrm{C}$ monolayers in Mayer, 1999). It seems most likely that a close correlation between the iron (oxyhydr)oxide content and the surface area simply arises because the iron (oxyhydr)oxides themselves constitute a significant fraction of the surface area, irrespective of any association with clay mineral surfaces (Ransom et al., 1997). In most cases, iron (oxyhydr)oxides attached to the surfaces of quartz 
and clay minerals apparently occur as patches, aggregates or layers of limited extent (e.g., Horowitz and Elrick, 1987; Postma and Brockenhuus-Schack, 1987). In some cases, small blebs or patches of iron (oxyhydr)oxides may also infill mesopores on clay mineral surfaces (Poulton and Raiswell, 2005).

In samples from natural settings, electron microscopy observations (Greenland et al., 1968; Tipping et al., 1981; Poulton and Raiswell, 2005) have also shown that poorly ordered iron (oxyhydr)oxides commonly occur as spheroidal to ellipsoidal nanoparticles that may be single or aggregated, and may be free-standing or attached to quartz or clay minerals. A nanoparticulate fine-structure is also sometimes visible in the layers or patches attached to quartz and clay minerals (e.g., see Horowitz and Elrick, 1987; Postma and Brockenhuus-Schack, 1987). The reasons for the aggregation of iron (oxyhydr)oxide nanoparticles and their attachment to other minerals are not well understood but are likely to be related to attractive or repulsive interactions with the surface active sites on quartz and clay minerals (see below).

\subsection{Morphology of iron (oxyhdr)oxides in glacial sediments}

The FEG-SEM images of all the glacial sediments described in this study show the presence of poorly ordered nanoparticles. They may be single nanoparticles with sizes in the order of $<10 \mathrm{~nm}$ or assembled into aggregates or blebs of up to several hundred nanometer diameter (Fig. 1). Similar nanoparticles are found in all the samples, although there are obvious differences in abundance that are roughly consistent with $\mathrm{Fe}_{\mathrm{HR}}$ content (Table 1); for example between Argentiere $\left(0.25 \% \mathrm{Fe}_{\mathrm{HR}}\right)$ and Finsterwalderbreen $\left(5.5 \% \mathrm{Fe}_{\mathrm{HR}}\right)$. Nanoparticles apparently occur in association with the surfaces of (alumino)silicate grains, both in isolation and also aggregated into patches. In other cases, nanoparticles are not apparently associated with host grains, but can still occur either as single grains or as aggregates. In addition, in some cases (i.e., Les Bossons and Orwell) iron nanoparticles were associated with organic matter, as has been shown previously by Wen et al. (1999). It seems unlikely that this variety of occurrences could be an artefact of sample preparation alone, but

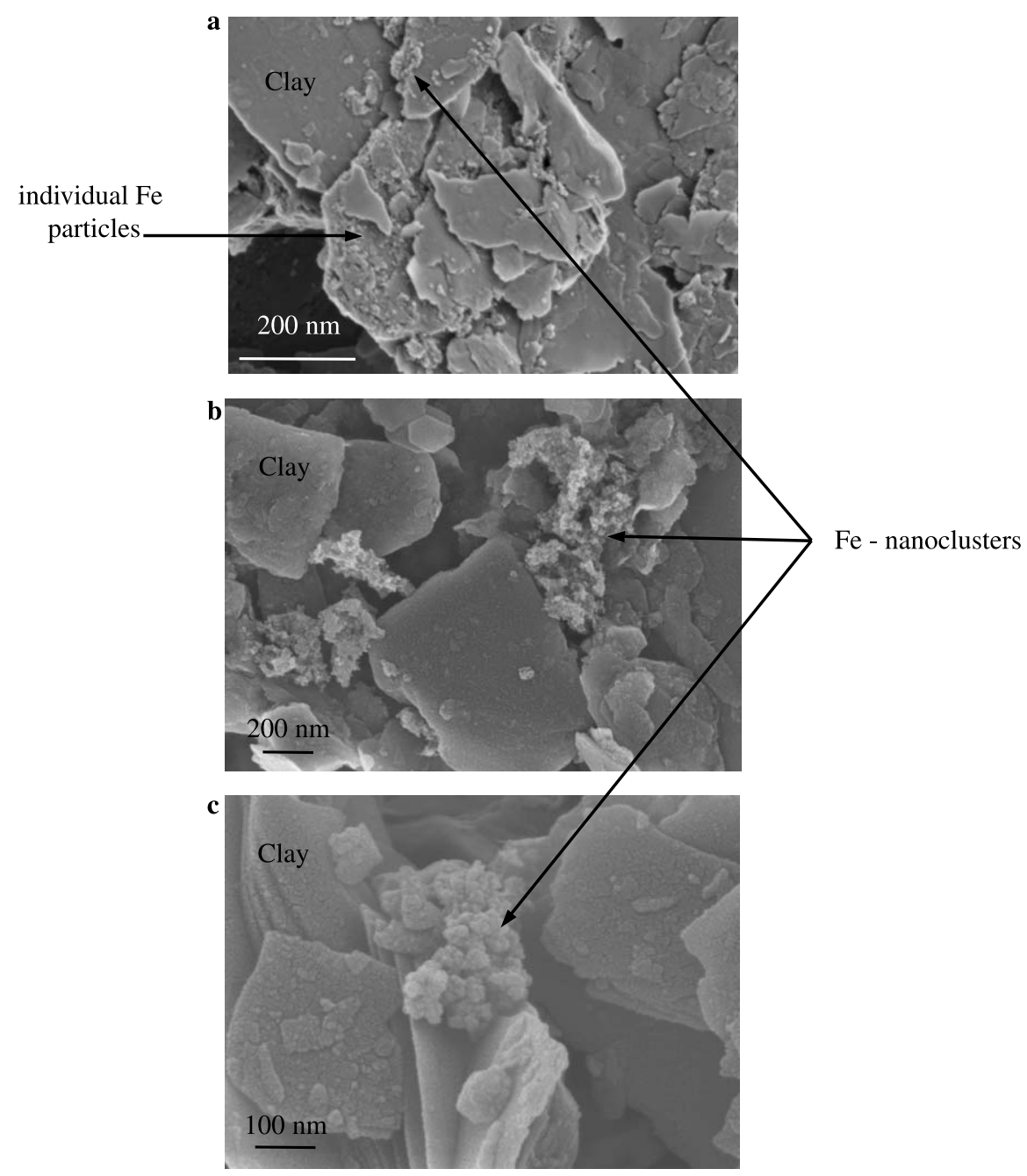

Fig. 1. High-resolution FEG-SEM images of the $<2 \mu \mathrm{m}$ fraction of glacial sediments from (a) Finsterwalderbreen, (b) Canada Glacier, and (c) Les Bossons showing the intimate association of clays and iron (oxyhydr)oxide clusters and nanoparticles. 

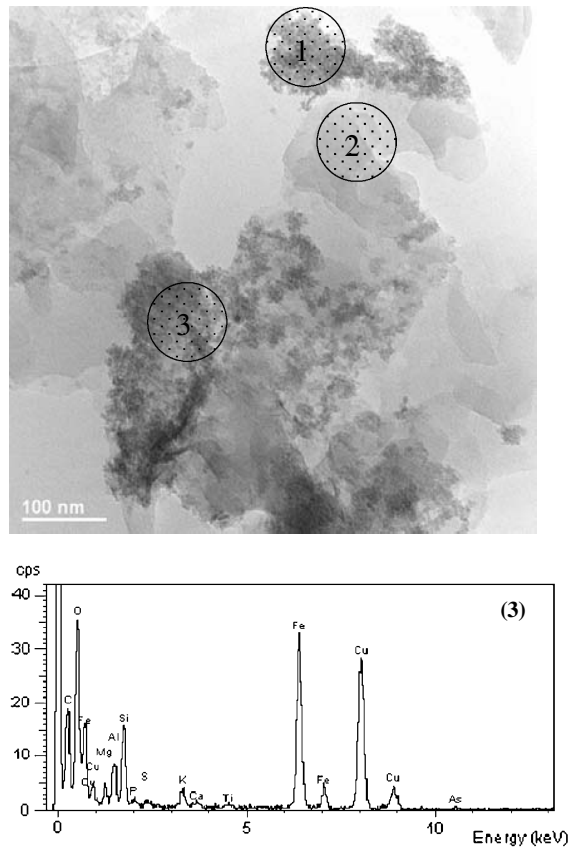
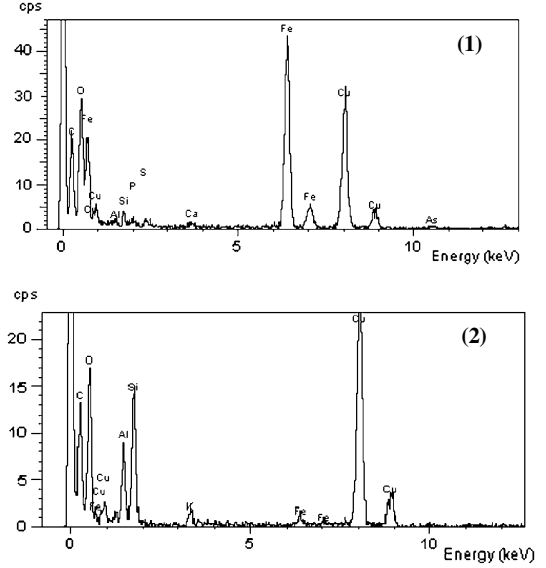

Fig. 2. FEG-TEM image and EDS patterns of selected areas in the Finsterwalderbreen $<2 \mu \mathrm{m}$ fraction; EDS point analyses on (1) an iron (oxyhydr)oxide cluster, (2) clay platelets, and (3) an iron (oxyhydr)oxide cluster on clays.

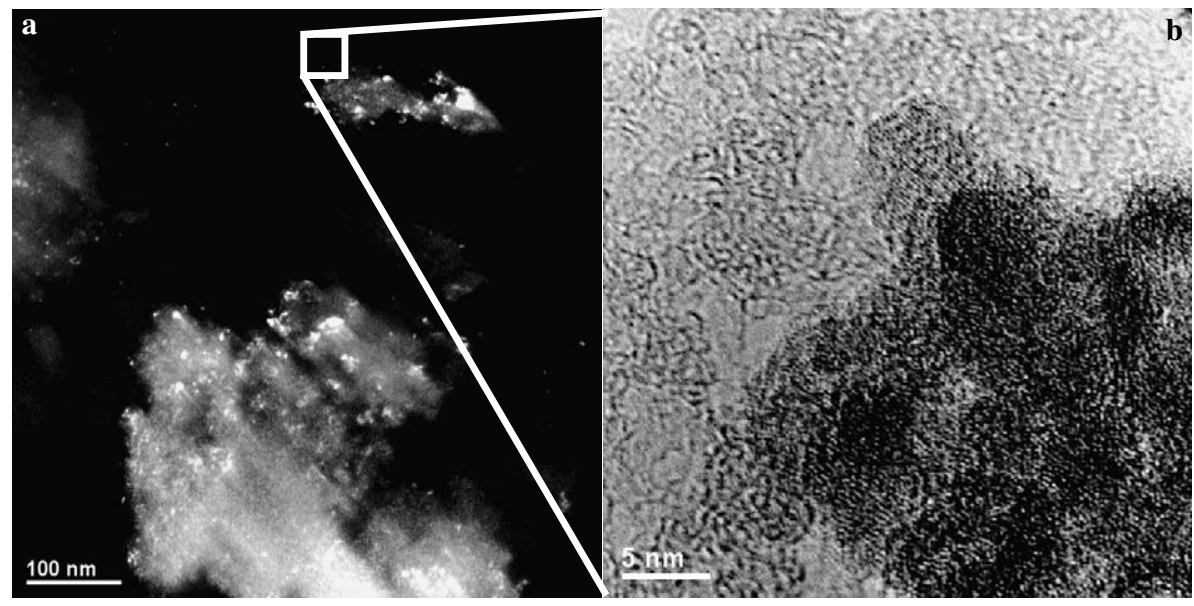

Fig. 3. (a) FEG-TEM dark field image of the area in Fig. 2 showing the iron rich clusters (bright areas) and individual particles, (b) high-resolution FEG-TEM image of a poorly ordered iron (oxyhydr)oxide nanoparticle cluster showing single hexagonal shaped nanoparticles of $\sim 5 \mathrm{~nm}$ diameter.

aggregation and attachment may have induced during sample preparation. Fig. 2 shows a FEG-TEM image and the corresponding EDS spectra for three areas of the $<2 \mu \mathrm{m}$ fraction Finsterwalderbreen sample. The large peaks for $\mathrm{C}$ and $\mathrm{Cu}$ are due to the carbon support film and the copper grid. Area 2 represents a clay grain devoid of nanoparticles, which shows predominantly $\mathrm{Si}$ and $\mathrm{Al}$ peaks. Little $\mathrm{Fe}$ is present in this area, but $\mathrm{Fe}$ becomes increasingly abundant in passing from area 3 (nanoparticle aggregate on a clay surface) to area 1 (nanoparticle aggregate isolated from host grains). Fig. 3a is a darkfield representation of the image in Fig. 2 and the brighter areas show the distribution of iron-rich clusters and individual particles dispersed on a clay surface. Examining one of these bright areas at high-resolution (Fig. 3b) reveals poorly ordered iron (oxyhdr)oxide nanoparticles with a faint hexagonal outline (diameter approximately $5 \mathrm{~nm}$ ) which are similar in morphology and size to ferrihydrite (Janney et al., 2000). The chemical and spectroscopic confirmation that such particles and aggregates are iron-based is shown in Fig. 4, where a FEG-TEM image of an area containing individual nanoparticles and nanoparticle clusters on a clay substrate (Fig. 4a) and the associated EELS elemental $\mathrm{Fe}$ map of the same field of view (Fig. 4b), show a close correspondence between nanoparticles and the bright Fe-rich areas. These figures provide compelling evidence that nanoparticles with this morphology are mainly composed of $\mathrm{Fe}$ (oxyhydr)oxides. Similar occurrences of nanoparticles 

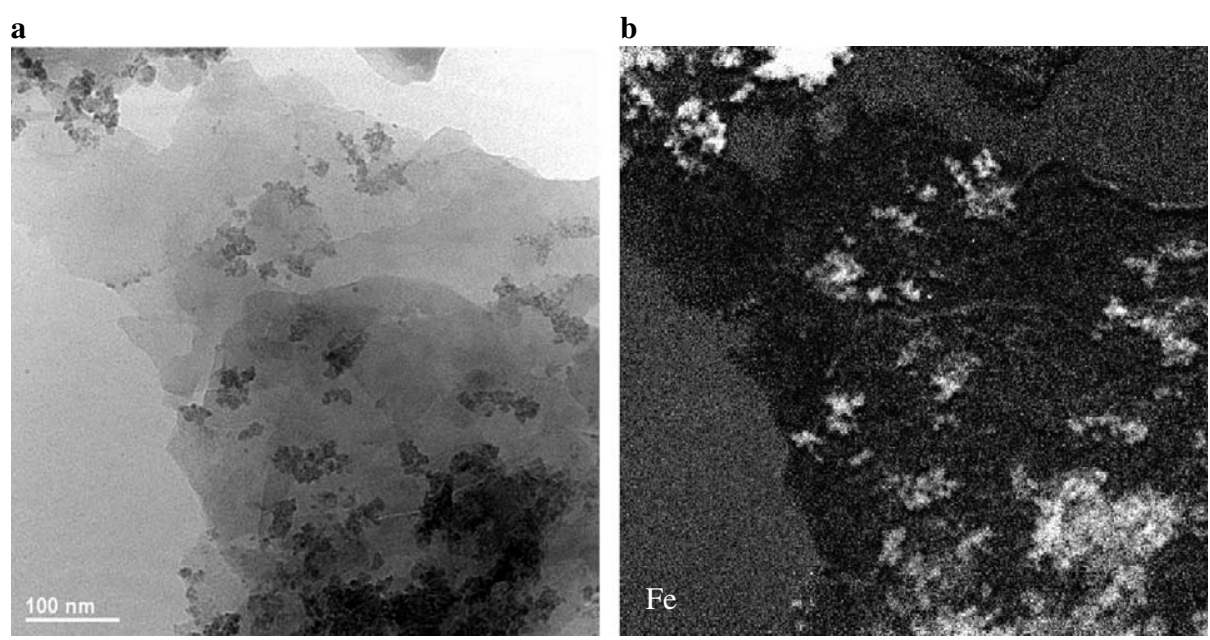

Fig. 4. FEG-TEM image of a similar area in the same sample showing (a) nanoparticle clusters and clay particles and (b) the associated EELS Fe-map with brighter iron-rich areas; note that map is slightly offset from the image due to drift.

were observed in all the glacial samples studied, irrespective of location and glacial bedrock composition.

\subsection{Interactions of iron (oxyhydr) oxide nanoparticulates in seawater}

Our SEM/TEM observations suggest that iron (oxyhydr)oxides occur in a wide range of forms; as single grains or coalesced into patches (both attached to glacial sediment grains) and as unattached nanoparticles (either single or aggregated). The nature of these associations between nanoparticulates, and between nanoparticulates and sediment grains may exert an important influence on the partition of bioavailable iron between the operationally defined dissolved and particulate fractions.

Two major types of intermolecular forces and interaction can occur between particles (Krupp, 1967; Israelachvili, 1992). Short-range interactions that arise from various types of chemical bonds (usually generated by ionisation of surface substrate groups) are always attractive (see below). However, long-range interactions arise from van der Waals forces and electrostatic forces (e.g., dipole-dipole and double layer interactions); the former are weaker and are always attractive but the latter can be either attractive or repulsive.

A repulsive electrostatic force arises from the overlap of the double layers of adjacent nanoparticles and can prevent aggregation. The electrostatic energy $\left(E_{\mathrm{D}}\right)$ arising from this repulsion depends on the double layer thickness as shown in the following equation from Hogg et al. (1966);

$E_{\mathrm{D}}=\pi \varepsilon \varepsilon_{\mathrm{o}} \psi_{\mathrm{D}}^{2} D \ln \left[1+\mathrm{e}^{-\kappa(S-D)}\right]$,

where $\varepsilon$ is the dielectric constant of water at the specified temperature, $\varepsilon_{\mathrm{O}}$ is the permittivity of free space $\left(8.845 \times 10^{-12} \mathrm{C}^{2} \mathrm{~J}^{-1} \mathrm{~m}^{-1}\right), \psi_{\mathrm{D}}$ is the surface charge density in $V$, and $\kappa^{-1}$ is the double layer thickness in $\mathrm{m}$. The reciprocal thickness of the double layer (Stumm, 1992) can be calculated from; $\kappa=\left[\left(2 F^{2} I \times 10^{3}\right) /\left(\varepsilon \varepsilon_{\mathrm{o}} R T\right)\right]^{0.5}$,

where $R$ is the molar gas constant $\left(8.314 \mathrm{~J} \mathrm{~mol}^{-1} \mathrm{~K}^{-1}\right), T$ is the temperature in $\mathrm{K}, F$ is the Faraday constant $\left(96,490 \mathrm{C} \mathrm{mol}^{-1}\right)$ and $I$ is the the ionic strength. Millero (2001) gives values of $\varepsilon$ of 87.7 at $0{ }^{\circ} \mathrm{C}$, so $\kappa^{-1}$ is approximately $10 \mathrm{~nm}$ in glacial meltwaters with $I<0.001 \mathrm{M} \mathrm{L}^{-1}$ (Raiswell, 1984) and approximately $0.36 \mathrm{~nm}$ in seawater $(I=0.72 \mathrm{M})$. Temperature changes have little effect (see Eq. (2)) because $\varepsilon$ decreases with increasing temperature (to 83.8 at $10^{\circ} \mathrm{C}$ or $283 \mathrm{~K}$ ). This collapse of the double layer limits the range over which the double layer repulsion forces operate and thus allows nanoparticles with the same charge sign to approach closely enough ( $\sim 0.3 \mathrm{~nm}$ or less) for bonding forces become effective Bonding forces may be an order of magnitude stronger than electrostatic forces (see below and Waychunas, 2001) and are thus able to produce aggregation. The effects of aggregation on bioavailability are unknown although we note that aggregates that are small enough to pass through a membrane filter will be recorded as dissolved (and presumed bioavailable) but larger aggregates will be removed by filtration (and assumed to be non-bioavailable).

The sign of $E_{\mathrm{D}}$ in Eq. (1) depends on $\psi_{\mathrm{D}}$ (the surface potential) and may produce an attraction between oppositely charged nanoparticles and other sediment grains. The existence of surface charge in metal oxides arises from the ionisation of surface $(\mathrm{S})$ hydroxyls

$$
\mathrm{S}-\mathrm{OH}_{2}{ }^{+} \leftrightarrow \mathrm{S}-\mathrm{OH}+\mathrm{H}^{+} \leftrightarrow \mathrm{S}^{-} \mathrm{O}^{-}+\mathrm{H}_{2} \mathrm{O}
$$

with protonation favoured under acidic conditions and deprotonation under in alkaline solutions. The surface charge of oxides is thus controlled by $\mathrm{pH}$ (and to a lesser extent by ionic strength) and is positive below a characteristic $\mathrm{pH}$ (the point of zero charge or PZC). Cornell and Schwertmann (2003) report that the PZC of pure iron (oxyhydr)oxides lies in the following ranges; ferrihydrite 7.8-7.9, lepidocrocite 6.7-7.3, hematite 7.5-9.5, and 
goethite 7.5-9.5. A rough estimate of $\psi_{\mathrm{D}}$ can be made (Stumm, 1992) from;

$\psi_{\mathrm{D}}=2.3 R T\left(\mathrm{pH}_{\mathrm{ZPC}}-\mathrm{pH}\right) / \mathrm{F}$.

The $\mathrm{pH}$ of glacial meltwaters typically lies in the range 6.5-8.5 (Raiswell, 1984) and thus pure iron (oxyhydr)oxides in meltwaters may have surface charges ranging from +70 to $-160 \mathrm{mV}$ or $+70 \mathrm{mV}$ to $-70 \mathrm{mV}$ in seawater at $\mathrm{pH} 8$.

However, the surface charges of iron (oxyhydr)oxides may be considerably modified by adsorbed ions, organic matter or non-ideal pure phases. In dilute natural waters iron (oxyhydr)oxides specifically adsorb chloride, sulfate, and nitrate ions (Cornell and Schwertmann, 2003), which are relatively abundant in most in glacial meltwaters (Brown, 2002). These adsorbed ions add negative charge to the (oxyhydr)oxide surface and hence shift the PZC to lower pH values. For example, Matijevic (1980) showed that the electrophoretic mobility of spherical hematite grains at $\mathrm{pH} 7$ was close to zero but the PZC was shifted to approximately 6 in the presence of adsorbed $\mathrm{Cl}^{-}$, indicating a $\psi_{\mathrm{D}}$ of approximately $-50 \mathrm{mV}$. Tipping (1981) and Tipping and Cooke (1982) also observed that the adsorption of humic material decreased the PZC of nanoparticulate goethite, hematite, and ferrihydrite in freshwaters such that the (oxyhydr)oxide surfaces were negatively charged with a surface charge potential of approximately $-27 \mathrm{mV}$.

Thus, the literature data suggest that iron (oxyhydr)oxide nanoparticles typically have $\psi_{\mathrm{D}}$ values ranging from $+70 \mathrm{mV}$ to $-70 \mathrm{mV}$ in seawater. Positively charged iron (oxyhydr)oxides will experience an electrostatic attraction to negatively charged (alumino)silicates. Many common (alumino)silicate minerals possess negative surface charge due to the isomorphic substitution of $\mathrm{Si}$ and $\mathrm{Al}$ for less positive valence ions, or to the $\mathrm{pH}$-dependent charges (see earlier) that form on surface hydroxyls (Al-OH, Si-OH) situated at broken edges (Van Olphen, 1963; Sposito, 1989). Once in close proximity (oxyhydr)oxide nanoparticles will bond with surface hydroxyl groups on quartz and (alumino)silicate minerals via surface complexation or hydrogen bonds. Hydrogen bond or dipole-dipole forces are relatively strong $(10-40 \mathrm{~kJ} / \mathrm{mol}$ for $\mathrm{H}$-bond and up to $\sim 200 \mathrm{~kJ} / \mathrm{mol}$ for dipole-dipole forces) and are 100-1000 times stronger than van der Waals forces. The abundance of (alumino)silicate grains makes their close approach, collision and bonding with nanoparticulates very probable once glacial sediment has been delivered into the ocean. Such nanoparticles (and the larger nanoparticulate aggregates) are removed with the sediment by filtration but may still be bioavailable, either directly (due to enhanced solubility) or indirectly (due to photochemical processes).

\section{The global iron (oxyhydr)oxide cycle}

This section utilises the new estimates of glacial iron (oxyhyd)oxide fluxes to construct a global iron (oxyhydr)oxide cycle (Fig. 5), dividing the ocean into two compartments; a continental shelf reservoir restricted to water depths of less than $1 \mathrm{~km}$, and an open ocean reservoir for water depths greater than $1 \mathrm{~km}$. The sources of iron (oxyhydr)oxides considered here are derived from the dissolved iron and particulate iron (oxyhydr)oxide $\left(\mathrm{Fe}_{\mathrm{HR}}\right)$ fluxes originating from rivers, glaciers, groundwaters, aeolian dust, hydrothermal activity, coastal erosion, and diagenetic recycling. The major sinks are estuarine removal and deposition into continental shelf and deep sea sediments. Each of these sources is briefly quantified below and further details can be found in Poulton and Raiswell (2002) and Raiswell and Anderson (2005), and sources therein.

\subsection{Riverine fluxes}

Estimates of dissolved riverine fluxes (defined as the $\mathrm{Fe}$ which is able to pass through a $0.45 \mu \mathrm{m}$ filter) into the oceans fall in a fairly narrow range from 0.2 to $2.0 \mathrm{Tg} \mathrm{yr}^{-1}$ (Wollast and Mackenzie, 1983; Haese, 2000; de Baar and de Jong, 2001). Ranges estimated here are expressed as a

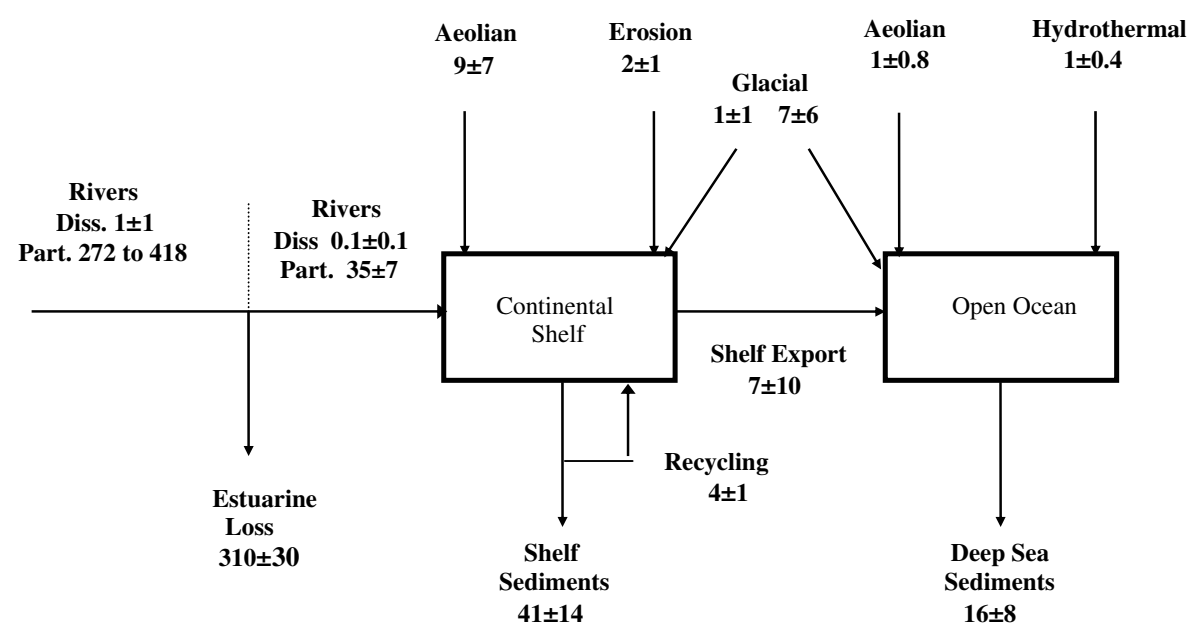

Fig. 5. The global iron (oxyhydr)oxide cycle. Units in ${\operatorname{Tg~} y r^{-1}}^{-}$ 
mean $\pm 3 \mathrm{SD}$, giving a dissolved flux of $1 \pm 1 \mathrm{Tg} \mathrm{yr}^{-1}$. Estimates of particulate fluxes are, however, considerably more variable than dissolved fluxes for a variety of reasons. Sediment discharge data show substantial temporal variability on timescales which range from hourly to annually (Horowitz et al., 2001). Furthermore, in many regions sediment discharge measurements are made infrequently and/or over timescales that are too short to permit a sensible mean annual flux to be estimated. There is also relatively little data for many rivers during large floods, when the mean annual sediment discharge may be delivered over several days. Thus, it is extremely difficult to estimate mean annual sediment discharge on decadal and centennial timescales (Hay, 1998; Poulton and Raiswell, 2002). However, much of the dissolved iron and particulate iron (oxyhydr)oxides are removed from the riverine load during passage through estuaries (see earlier and de Baar and de Jong, 2001). For example, a variety of studies have shown that colloidal iron (oxyhydr)oxides are $70-100 \%$ removed during passage through a salinity gradient into seawater (Moore et al., 1979; Dai and Martin, 1995; Wen et al., 1999). Poulton and Raiswell (2002) estimate the suspended sediment iron (oxyhydr)oxide load ranges from 272 to $418 \mathrm{Tg} \mathrm{yr}^{-1}$ of $\mathrm{Fe}$ as oxide. This range encompasses the differences between rivers with large flood plains that store significant fractions of the riverine load (e.g., the Brahmaputra; Allison et al., 1998) as compared to rivers from high-standing islands where storage is minimal (Milliman et al., 1999; Lyons et al., 2002). The removal of $90 \%$ of this flux in estuaries suggests that the $\mathrm{Fe}_{\mathrm{HR}}$ flux actually delivered into the oceans is $35 \pm 7 \mathrm{Tg} \mathrm{yr}^{-1}$ (see Fig. 5).

\subsection{Groundwater fluxes}

Submarine groundwater discharge (SGD) not only includes the discharge of meteoric groundwater but all advective flow between the land and the continental shelf (Burnett et al., 2003) that may be induced by pressure and density gradients (Moore and Wilson, 2005). The importance of SGD varies regionally as a proportion of the total water flux from almost nothing to $100 \%$ (Taniguchi et al., 2002). Estimates of the global SGD flux entering the oceans vary from $0.01 \%$ to $10 \%$ of the surface water runoff, with a best estimate of $5 \%$ or $1.85 \times 10^{15} \mathrm{~L} \mathrm{yr}^{-1}$ (Slomp and Van Cappellen, 2004). However, compilations of groundwater analyses (Langmuir, 1997) show a median dissolved $\mathrm{Fe}$ content of $100 \mu \mathrm{g} \mathrm{L}^{-1}$ and thus this combination of discharge and concentration levels is unlikely to produce a dissolved

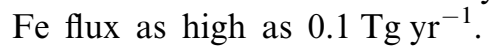

\subsection{Coastal erosion}

Material derived from coastal erosion constitutes a further addition of sediment to the ocean basins. Garrels and Mackenzie (1971) estimate this flux to be $200-900 \mathrm{Tg} \mathrm{yr}^{-1}$, with a preferred value of $250 \mathrm{Tg} \mathrm{yr}^{-1}$ (close to the
$150 \mathrm{Tg} \mathrm{yr}^{-1}$ estimated by Lisitzin, 1972). A flux of $200 \mathrm{Tg} \mathrm{yr}^{-1}$ with the average $\mathrm{Fe}_{\mathrm{HR}}$ content of coastal marine sediments $(1.0 \pm 0.5 \%$; Poulton and Raiswell, 2002) indicates an erosive flux of $2 \pm 1 \mathrm{Tg} \mathrm{yr}^{-1}$ of $\mathrm{Fe}_{\mathrm{HR}}$ (see Fig. 5).

\subsection{Hydrothermal flux}

Iron can also be delivered to the open ocean reservoir as a result of interactions between basaltic lavas and seawater, by axial high temperature and diffuse low temperature activity, and by off-axis low temperature activity and the weathering of hot and cold basalt on the seafloor. Estimates of $1-10 \mathrm{Tg} \mathrm{yr}^{-1}$ for the axial high temperature and diffuse low temperature flow have been made by Elderfield and Schlutz (1996). Poulton and Raiswell (2002) estimate that the off-axis low temperature flux is $1 \mathrm{Tg} \mathrm{yr}^{-1}$, while the contribution from basaltic weathering gives a further $7 \mathrm{Tg} \mathrm{yr}^{-1}$ (Maynard, 1976; Wolery and Sleep, 1976). Hence the combined flux from all hydrothermal sources can be estimated to be $14 \pm 5 \mathrm{Tg} \mathrm{yr}^{-1}$ (Poulton and Raiswell, 2002). However, these inputs are dispersed over relatively small areas of ocean basin sediment that are not included in the samples used by Raiswell and Canfield (1998) to derive a mean $\mathrm{Fe}_{\mathrm{HR}}$ content for deep sea sediments $(1.0 \pm 0.5 \%)$. Here, we arbitrarily assume that $10 \%$ of the hydrothermal flux (or $1 \pm 0.4 \mathrm{Tg} \mathrm{yr}^{-1}$ ) is dispersed sufficiently widely to contribute to our mean deep sea sediment composition (see Fig. 5), which then allows the deep sea sediment $\mathrm{Fe}_{\mathrm{HR}}$ data to be used to derive a shelf export flux of $\mathrm{Fe}_{\mathrm{HR}}$ to the open ocean reservoir (see below).

\subsection{Glacial flux}

Above we estimated the glacial fluxes from ice sheets plus smaller glaciers as $1400 \mathrm{Tg} \mathrm{yr}^{-1}$ with a further $1500 \mathrm{Tg} \mathrm{yr}^{-1}$ supplied by icebergs. Assuming these sediment fluxes have a mean $\mathrm{Fe}_{\mathrm{HR}}$ content of $0.5 \pm 0.4 \%$ (Poulton and Raiswell, 2002) produces an overall $\mathrm{Fe}_{\mathrm{HR}}$ flux of $14 \pm 11 \mathrm{Tg} \mathrm{yr}^{-1}$. However, much of the sediment flux carried by meltwater runoff is likely to be physically trapped in fjords. Furthermore, the transfer of colloidal and particulate-associated $\mathrm{Fe}_{\mathrm{HR}}$ to the oceans through estuaries is unlikely to be more efficient than by rivers and thus, assuming a $10 \%$ transfer (as for riverine delivery), produces an $\mathrm{Fe}_{\mathrm{HR}}$ flux of $1 \pm 1 \mathrm{Tg} \mathrm{yr}^{-1}$ to the shelf reservoir. By contrast the sediment flux from icebergs $\left(1500 \mathrm{Tg} \mathrm{yr}^{-} 1\right)$ occurs directly into the open ocean reservoir (although there is some loss in near shore regions; Dowdeswell and Scourse, 1990) and thus delivers $\mathrm{Fe}_{\mathrm{HR}}$ at a rate of $7 \pm 6 \mathrm{Tg} \mathrm{yr}^{-1}$ (see Fig. 5). The aeolian dust flux released from melting icebergs is relatively small (6 $\mathrm{Tg} \mathrm{yr}^{-1}$, see earlier) and assuming an $\mathrm{Fe}_{\mathrm{HR}}$ content of $\sim 1 \%$ (Poulton and Raiswell, 2002), produces an $\mathrm{Fe}_{\mathrm{HR}}$ flux of only $0.06 \mathrm{Tg} \mathrm{yr}^{-1}$. This flux is small enough to be ignored in comparison to the other glacial $\mathrm{Fe}_{\mathrm{HR}}$ sources. 


\subsection{Aeolian dust}

Duce et al. (1991) have estimated the mineral aerosol flux to the oceans as $910 \mathrm{Tg} \mathrm{yr}^{-1}$. Based on this data the total iron flux is estimated as $25 \pm 10 \mathrm{Tg} \mathrm{yr}^{-1}$ (de Baar and de Jong, 2001; Jickells and Spokes, 2001) while the $\mathrm{Fe}_{\mathrm{HR}}$ flux is $10 \pm 4$ (Poulton and Raiswell, 2002). Digitising the dust flux maps of GESAMP (1990) and interpolating the data between depth contours suggests that $\approx 90 \%$ of the dust falls into water $<1 \mathrm{~km}$ in depth. Thus the aeolian flux of $\mathrm{Fe}_{\mathrm{HR}}$ into the shelf reservoir is $9 \pm 7 \mathrm{Tg} \mathrm{yr}^{-1}$ and into the open ocean is $1 \pm 0.8 \mathrm{Tg} \mathrm{yr}^{-1}$ (see Fig. 5).

\subsection{Diagenetic recycling}

Recent benthic chamber measurements (McManus et al., 1997; Elrod et al., 2004) have shown that dissolved iron is supplied from anoxic sediment porewaters to overlying seawater by diffusion and bioirrigation. The re-suspension of anoxic shelf sediments may also release dissolved iron-rich porewaters to overlying seawater (Johnson et al., 1999) which may result in the precipitation and export of iron (oxyhydr)oxides (Aller et al., 1986; Raiswell and Anderson, 2005). Re-suspension appears to be patchy in distribution across the shelf (Hutchins et al., 1998) and such non-steady state effects are difficult to quantify. Diffusive fluxes vary greatly with porewater $\mathrm{pH}$, dissolved $\mathrm{Fe}$ concentrations, bottom water oxygenation, temperature, and the thickness of the surface layer of oxygenated sediment (Raiswell and Anderson, 2005) and reliable flux measurements are currently available for relatively few sites. However, Elrod et al. (2004) give a mean flux of diagenetically recycled iron from shelf sediments as $5 \mathrm{Tg} \mathrm{yr}^{-1}$. This value is consistent with that derived by Poulton and Raiswell (2002) based on estimates of the authigenic iron flux to deep-sea sediments, but somewhat larger than the 2$3 \mathrm{Tg} \mathrm{yr}^{-1}$ estimated by de Baar and de Jong (2001). A mean value of $4 \pm 1 \mathrm{Tg} \mathrm{yr}^{-1}$ is used in Fig. 5 for the combined inputs from diffusion, re-suspension, and bioirrigation.

\subsection{The global iron (oxyhydr)oxide cycle}

Fig. 5 shows all the major inputs to the $\mathrm{Fe}_{\mathrm{HR}}$ cycle. An estimate of the rate of $\mathrm{Fe}_{\mathrm{HR}}$ removal to deep sea sediments can be made from the data of Martin and Windom (1991), who give the accumulation rate of sediments in water $>1 \mathrm{~km}$ depth as $1100 \mathrm{Tg} \mathrm{yr}^{-1}$. Higher estimates of the deep sea sedimentation rate by Hay (1994) suggest a value of $2800 \mathrm{Tg} \mathrm{yr}^{-1}$ and an approximate mean of $1500 \pm 500 \mathrm{Tg} \mathrm{yr}^{-1}$ is used here. Poulton and Raiswell (2002) give a mean $\mathrm{Fe}_{\mathrm{HR}}$ content of $1.0 \pm 0.5 \%$ for deepsea sediments (carbonate-corrected), thus producing a removal rate of $16 \pm 8 \mathrm{Tg} \mathrm{yr}^{-1}$ of $\mathrm{Fe}_{\mathrm{HR}}$.

Most of the fluxes in Fig. 5 are derived from independent estimates, except for shelf export and removal to shelf sediments (which have been derived by mass balance assuming a steady state). The large uncertainties in these two fluxes (shelf export $7 \pm 10 \mathrm{Tg} \mathrm{yr}^{-1}$; removal to shelf sediments $41 \pm 14 \mathrm{Tg} \mathrm{yr}^{-1}$ ) arises because mass balances critically depend on the large, poorly known flux values for the riverine suspended load, the transport of Fe (oxyhydr)oxides through estuaries (see earlier) and the removal of Fe to deep-sea sediments (see above). Further data from the high-standing islands may allow an independent estimate of the proportion of their riverine fluxes that is exported across the shelf into the open ocean (see Sholkovitz et al., 1999) but at present the estimates for shelf export and removal to shelf sediments should only be regarded as indicative. Bearing this in mind, Fig. 5 shows the following significant features of the global iron (oxyhydr)oxide cycle.

(i) The main sources of iron (oxyhydr)oxides to the shelves are from rivers, aeolian dust, and diagenetic recycling.

(ii) The main non-hydrothermal sources of iron (oxyhydr)oxides to the open ocean are delivered by icebergs and by transport through (or from) the continental shelf.

These conclusions refer solely to the masses of iron present as (oxyhydr)oxides the bioavailability of which is discussed below. The bioavailability of aeolian material has been the subject of detailed study (see Jickells and Spokes, 2001) but otherwise only general comments can be made on the bioavailability of the other fluxes, all of which would benefit from further study. Colloidal iron (including nanoparticulates not attached to sediment grains) is almost quantitatively removed from most riverine loads during passage through estuaries (see above). However, iron (oxyhydr)oxide nanoparticles that are attached to sediment grains may pass through estuaries as suspended load. These attached nanoparticulates may be partially bioavailable depending on the factors that control solubility (surface area, crystallinity, mineralogy, and photochemical reactivity), but their most probable fate is rapid sedimentation on to the shelf, from which a fraction may be recycled. This is also the likely fate of iron (oxyhydr)oxide material produced by coastal erosion. Anoxic diagenesis of shelf sediments produces reduced iron, a fraction of which diffuses up through the sediment porewaters into the overlying seawater (Raiswell and Anderson, 2005). Here, rapid oxidation will produce fresh iron (hydr)oxide nanoparticles (Shaw et al., 2004) that are potentially bioavailable, but are believed to be mainly used in sustaining near-shore productivity (Fung et al., 2000; Elrod et al., 2004).

The delivery of iron (oxyhydr)oxides to the open ocean is here shown to be mainly derived by export from the shelf plus iceberg supply. However, the exact origin and pathways of the material exported from the shelf to the deep sea are currently unknown. Anderson and Raiswell (2004) have evaluated a number of possible processes that could supply iron (oxyhydr)oxides to the deep basin Black Sea (the most likely being diagenetic recycling, 
fractionation of the riverine flux and microbial degradation of aluminosilicates). In the present context, the bioavailable iron produced by diagenetic recycling seems unlikely to escape the shelf (see above). However, there is evidence that riverine particulates can undergo long-range transport into deep basin areas. For example rivers draining the active margins of islands in the East Indies deliver fine particulates into the Equatorial Undercurrent, allowing longrange transport across the Pacific (Gordon et al., 1997; Milliman et al., 1999; Sholkovitz et al., 1999; Mackey et al., 2002). It seems unlikely that bioavailable material would survive transport across the shelf and into the open ocean but this has not been established.

The new estimates of glacial sediment supply produced here show that significant amounts of iron (oxyhydro)oxides can be transported to the open ocean by iceberg delivery. In contrast to a fractionated riverine flux, the sediments delivered from icebergs may not have aged significantly before melting releases the sediments to the oceans. Iron (oxyhydro)oxides may form in aqueous subglacial environments prior to their incorporation with other glacial debris into basal ice. These subglacial environments are regions where sediment is actively sheared (Alley et al., 1989). Sediment surfaces are therefore more likely to be comminuted and reactivated in these environments, rather than aged. Some aging may occur in the basal ice of the ice bergs during melting, but this is likely to be on the timescale of days to months, and much shorter than the wetting time of sediment in transit through a fluvio-glacial system. The amounts of iron (oxyhydr)oxides in glacial debris are generally low but minimal aging may allow the preservation of poorly crystalline nanoparticulates of high bioavailability. Icebergs may deposit sediment over $62 \times 10^{6} \mathrm{~km}^{2}$ of the Southern Ocean, with most icebergs being found south of $45^{\circ} \mathrm{S}$. Occasionally, some are found as far as $30^{\circ} \mathrm{S}$. Typically, ice rafted debris is found within $1000-1200 \mathrm{~km}$ of the Antarctic shoreline and this represents the area where iceberg delivery of nanoparticulate iron is likely to be most effective. This area includes regions close to Antartica (Weddell and Ross Seas, the islands of the Scotia Arc) where productivity is high, but also extends into more distant areas where productivity is low (Watson, 2001). However, iceberg delivery of iron (oxyhydr)oxides is likely to be very variable across this region. Different icebergs may contain different masses of iron (oxyhydr)oxides depending on their source area, and rates of melting will also alter delivery depending on the location of sediment within icebergs.

These glacially derived fluxes would also have been considerably larger during the Last Glacial Maximum (LGM) at $\sim 18,000-21,000$ years ago. During the LGM water fluxes from ice sheets are calculated to have increased to $\sim 1-$ $2 \mathrm{Tm}^{3} \mathrm{yr}^{-1}$ (Jones et al., 2002) and meltwater discharge from smaller ice cap and glaciers increased to $3-6 \mathrm{Tm}^{3} \mathrm{yr}^{-1}$ (Tranter, 2005), which together produce a sediment flux in the region of 4000-8000 $\mathrm{Tg} \mathrm{yr}^{-}$(Table 2). We estimate iceberg calving to be of the order of $6 \mathrm{Tm}^{3} \mathrm{yr}^{-1}$ from ice sheets, and 3-6 $\mathrm{Tm}^{3} \mathrm{yr}^{-1}$ from smaller ice masses (Table 2). The transfer of suspended sediment to the oceans by icebergs is therefore potentially $4500-6000 \mathrm{Tg} \mathrm{yr}^{-1}$ (or $5200 \pm 800 \mathrm{Tg} \mathrm{yr}^{-1}$ ) and this enhanced flux may have contributed $26 \pm 21 \mathrm{Tg} \mathrm{yr}^{-1}$ of $\mathrm{Fe}_{\mathrm{HR}}$ (over three times more than the present iceberg $\mathrm{Fe}_{\mathrm{HR}}$ flux).

Low concentrations of atmospheric $\mathrm{CO}_{2}$ are believed to occur during glacial periods (including the LGM) and have been attributed to an increased supply of iron-bearing aeolian dust to the oceans (Martin, 1990). Modelling suggests that approximately $50 \%$ of the $\mathrm{CO}_{2}$ drawdown (approximately $40 \mathrm{ppm}$ ) could be accounted for by iron-stimulated phytoplankton activity in the Southern Oceans (Watson et al., 2000; Watson, 2001). However, Maher and Dennis (2001) have criticised this iron fertilisation hypothesis on the grounds that the timing of the aeolian dust fluxes in the Vostok ice core does not correspond with periods of $\mathrm{CO}_{2}$ drawdown. Furthermore, Maher and Dennis (2001) point out that aeolian dust fluxes in the Southern Ocean are low, and were so even during glaciations.

The data presented here suggest another possibility; that increased fluxes of nanoparticulate iron derived from icebergs stimulated the increased productivity and produced the observed glacial $\mathrm{CO}_{2}$ drawdown. Increased iceberg production and slower melting during the LGM would also assist in transporting iron into more remote regions where productivity could be fertilised. Martin (1990) estimates that about 430,000 ton of $\mathrm{Fe}$ (or $0.4 \mathrm{Tg}$ ) would be required for sufficient extra productivity to generate the removal of the $3 \mathrm{Gt}$ (or $3000 \mathrm{Tg}$ ) of $\mathrm{C}$ required to increase ocean productivity and drawdown $\mathrm{CO}_{2}$ levels to those observed. Our data (Table 2) indicate that iceberg sediment delivery to the oceans increased by approximately $5000 \mathrm{Tg} \mathrm{yr}^{-1}$ during the LGM and thus, given a glacial sediment concentration of $\mathrm{Fe}_{\mathrm{HR}}$ of $0.5 \%$ (see earlier), icebergs transport an $\mathrm{Fe}_{\mathrm{HR}}$ flux equivalent to $20 \mathrm{Tg} \mathrm{yr}^{-1}$. Less than $0.02 \%$ of this flux would need to be bioavailable in order to fertilise the removal of $3 \mathrm{Gt}$ of $\mathrm{C}$.

We have not been able to estimate the proportion of nanoparticulate iron in our glacial samples, but we have shown that iron nanoparticulates are present in a wide variety of fine-grained glacial debris. The fine fractions of the samples in Table 1 typically comprise $\sim 1 \%$ of the bulk sample and mostly have $\mathrm{Fe}_{\mathrm{HR}}$ contents of at least $1 \%$. Iceberg delivery of an additional $50 \mathrm{Tg} \mathrm{yr}^{-1}$ of this material during the LGM. would therefore add at least $0.5 \mathrm{Tg} \mathrm{yr}^{-1}$ of $\mathrm{Fe}_{\mathrm{HR}}$ to the oceans. Thus the flux of $\mathrm{Fe}_{\mathrm{HR}}$ in the finest fraction alone is sufficient to fertilise oceanic removal of $\mathrm{CO}_{2}$, provided all the $\mathrm{Fe}_{\mathrm{HR}}$ in the finest fraction delivered by icebergs is nanoparticulate and/or bioavailable. Clearly glacial $\mathrm{Fe}_{\mathrm{HR}}$ fluxes are sufficiently large that the dissolution of only small proportions of this material may play a significant role in the delivery of bioavailable iron to the ocean. A more comprehensive study of material derived from icebergs is now required to ascertain the extent to which iron (oxyhydr)oxide nanoparticles are present in icebergs, their geographical distribution and bioavailability. 


\section{Conclusions}

1. Estimates of present-day glacial sediment delivery to the oceans have been made from modeling rates of ice-melting and the sediment content of ice. These estimates indicate that the sediment flux from meltwater discharge is $\sim 1400 \mathrm{Tg} \mathrm{yr}^{-1}$, with an additional $\sim 1500 \mathrm{Tg} \mathrm{yr}^{-1}$ from icebergs. These estimates are higher than the most recent best estimate of $800 \mathrm{Tg} \mathrm{yr}^{-1}$ by Hay (1998).

2. Iron is present as (oxyhydr)oxides only at low concentrations $\left(\mathrm{Fe}_{\mathrm{HR}}=0.5 \pm 0.4 \%\right.$; Poulton and Raiswell, 2002) in glacial sediments. However, large glacial sediment fluxes produce significant delivery rates of $\mathrm{Fe}_{\mathrm{HR}}$ into the oceans. The $\mathrm{Fe}_{\mathrm{HR}}$ carried by meltwaters $\left(14 \pm 11 \mathrm{Tg} \mathrm{yr}^{-1}\right)$ is likely to be substantially removed during estuarine transport, as is the present riverine $\mathrm{Fe}_{\mathrm{HR}}$ flux, and the combined effects of colloid removal and sedimentation may allow only $1 \pm 1 \mathrm{Tg} \mathrm{yr}^{-1}$ to reach the oceans. However, the sediment carried by icebergs evades estuarine transport and the removal of colloidal iron (oxyhydr)oxides to add $7 \pm 6 \mathrm{Tg} \mathrm{yr}^{-1} \mathrm{Fe}_{\mathrm{HR}}$ directly into the open ocean.

3. A global iron (oxyhydr)oxide model shows that the dominant fluxes of $\mathrm{Fe}_{\mathrm{HR}}$ to the continental shelf are from aeolian dust $\left(9 \pm 7 \mathrm{Tg} \mathrm{yr}^{-1}\right)$, coastal erosion $\left(2 \pm 1 \mathrm{Tg} \mathrm{yr}^{-1}\right)$, meltwater runoff from ice-sheets plus smaller glaciers $\left(1 \pm 1 \mathrm{Tg} \mathrm{yr}^{-1}\right)$ and diagenetic recycling $\left(4 \pm 1 \mathrm{Tg} \mathrm{yr}^{-1}\right)$. The main fluxes to the open ocean are from icebergs $\left(7 \pm 6 \mathrm{Tg} \mathrm{yr}^{-1}\right)$, aeolian dust $(1 \pm 0.8$

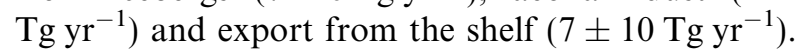

4. Detailed examination of the fine-grained fractions of sediment from Alpine, Arctic, and Antarctic glaciers shows the ubiquitous presence of iron (oxyhydr)oxide nanoparticles. Nanoparticles are typically smaller than $10 \mathrm{~nm}$ in diameter and are poorly ordered; they can occur as isolated grains (more often as aggregates) and may be separated from, or attached to, (alumino)silicate grains.

5. The mode of nanoparticulate iron delivery to the oceans is mainly controlled by surface charge potential, which can vary widely depending on mineralogy, crystallinity, and presence of adsorbed ions. The collapse of the double layer in seawater prevents long-range repulsion between adjacent nanoparticles and allows their approach to distances where bonding forces are effective. The resulting aggregates can may be small enough to pass membrane filters and be recorded as dissolved and bioavailable.

6. Nanoparticles with positive surface charge potentials will be attracted to (alumino)silicate grains which typically have large negative surface charge potentials. Nanoparticles attached to glacial sediment grains are removed by filtration but may still be bioavailable when delivered to the oceans via icebergs. Transport in a frozen matrix minimises the potential for aging and allows nanoparticles to retain high surface areas and poor-crys- tallinity that enhance solubility and bioavailability. Photochemical processes may also aid dissolution of nanoparticles.

7. Iceberg delivery of iron (oxyhydr)oxides to the deep sea during the LGM was large enough to fertilise increased oceanic productivity and drawdown sufficient $\mathrm{C}$ to produce low atmospheric $\mathrm{CO}_{2}$ levels.

\section{Acknowledgments}

Rob Raiswell is pleased to acknowledge his personal debt to Bob Berner. Firstly, through stimulating his interests in iron reactivity during a fruitful period of collaboration (and superb hospitality!) in the 1980s and secondly, in his encouragement to extend this interest to global geochemical cycles. The authors hope that Bob sees this paper as a reflection of his own scientific philosophy. The authors also thank Simon Poulton (Danish Centre for Earth System Science) for supplying samples from the Crary Ice Rise and the Campbell glacier, Dave Hatfield for iron analyses, Matt Smith for digitising the dust flux maps and Andy Brown from the LEEDS Electron Microscopy and Spectroscopy Centre for help with TEM and EELS data acquisition. We much appreciate the help from our reviewers in shaping this paper, especially Associate Editor Lee Kump.

Associate editor: Lee R. Kump

\section{References}

Aller, R.C., Mackin, J.E., Cox Jr., R.T., 1986. Diagenesis of Fe and S in Amazon inner shelf muds; apparent dominance of Fe reduction and implications for the genesis of ironstones. Cont. Shelf Res. 6, 263-289.

Allison, M.A., Kuehl, S.A., Martin, T.C., Hassan, A., 1998. Importance of flood plain sedimentation for river sediment budgets and terrigenous input to the oceans: insights from the Brahmaputra-Jamuna River. Geology 26, 175-178.

Alley, R.B., Blaankenship, D.D., Rooney, S.T., Bentley, C.R., 1989. Water-pressure coupling of sliding and bed deformation. III Application to Ice Stream B. Antarctica. J. Glaciol. 36, 130-139.

Anderson, T.F., Raiswell, R., 2004. Sources and mechanisms for the enrichment of highly reactive iron in euxinic Black Sea sediments. Am. J. Sci. 304, 203-233.

Angelis, M.De., Barkov, N.I., Petrov, V.N., 1987. Aerosol concentrations over the last climatic cycle (160 kyr) from an Antarctic ice core. Nature 325, 318-321.

Banfield, J.F., Zhang, H., 2001. Nanoparticles in the environment. Rev. Mineral. Geochem. 44, 1-58.

Barbeau, K., Moffett, J.W., 2000. Laboratory and field studies of colloidal iron oxide dissolution as mediated by phagotrophy and photolysis. Limnol. Oceanogr. 45, 827-835.

Bonneville, S., Van Cappellen, P., Behrends, T., 2004. Microbial reduction of iron (III) oxides: effects of mineral solubility and availability. Chem. Geol. 212, 255-268.

Boyle, E.A., Edmond, J.M., Sholkovitz, E.R., 1977. The mechanism of iron removal in Estuaries. Geochim. Cosmochim. Acta 41, 1313-1324.

Brown Jr., G.E., Henrich, V.E., Casey, W.H., Clark, D.L., Eggleston, C., Felmy, A.D., Goodman, D.W., Grätze, M., Maciel, G., McCarthy, M.I., Nealson, K.H., Sverjensky, D.A., Toney, M.F., Zachara, J.M., 1999. Metal oxide surfaces and their interactions with aqueous solutions and microbial organisms. Chem. Rev. 99, 77-174. 
Brown, G.H., 2002. Glacier meltwater hydrochemistry. Appl. Geochem. 17, 855-883.

Burnett, W.C., Bokuniewicz, H., Huettel, M., Moore, W.S., Taniguchi, M., 2003. Groundwater and pore water inputs to the coastal zone. Biogeochemistry 66, 3-33.

Church, J.A., Gregory, J.M., Huybrechts, P., Kuhn, M., Lambeck, K., Nhuan, M.T., Quin, D., Woodworth, P.L., 2001. Changes in sea level. In: Houghton, J.T., Ding, Y., Griggs, D.J., Noguer, P.J., van der Linden, M., Dai, X., Maskell, K., Johnson, C.A. (Eds.), Climate Change 2001: The Scientific Basis. Contribution of Working Group I to the Third Assessment Report of the Intergovernmental Panel on Climate Change. Cambridge University Press, Cambridge, pp. 639-693.

Cornell, R.M., Schwertmann, U., 2003. The Iron Oxides. Wiley, New York.

Dai, M., Martin, J.M., 1995. First data on trace metal level and behaviour in two major Arctic river-estuarine systems ( $\mathrm{Ob}$ and Yenisey) and in the adjacent Kara Sea. Earth Planet. Sci. Lett. 131, 127-141.

De'ath, R., 2004. Numerical modelling of iceberg flow, melt and sedimentation in the Eurasian Arctic during deglaciation. Unpublished Ph.D thesis, University of Bristol.

de Baar, M.J.W., de Jong, J.T.M., 2001. Distribution, sources and sinks of iron in seawater. In: Turner, D.R., Hunter, K.A. (Eds.), The Biogeochemistry of Iron in Seawater. Wiley, New York, pp. 123-253.

de Baar, H.J.W., Buma, A.G.J., Noltin, R.F., Cadee, G.C., Jaques, G., Treguer, P.J., 1990. On iron limitation of the Southern Ocean: experimental observations in the Weddell and Scotia seas. Mar. Ecol. Prog. Ser. 65, 105-122.

Dowdeswell, J.A., Dowdeswell, E.K., 1989. Debris in icebergs and rates of glaci-marine sedimentation: observations from Spitsbergen and a simple model. J. Geol. 97, 221-231.

Dowdeswell, J.A., Murray, T., 1990. Modelling rates of sedimentation from icebergs. In: Dowdeswell, J.A., Scourse, J.D. (Eds.), Glacimarine Environments: Processes and Sediments. Geol. Soc. London Spec. Publ. No. 53, pp. 121-137.

Dowdeswell, J.A., Scourse, J.D., 1990. On the description and modelling of glacimarine sediments and sedimentation. In: Dowdeswell, J.A., Scourse J.D. (Eds.), Glacimarine Environments: Processes and Sediments. Geol. Soc. London Spec, Publ. No. 53, pp. 1-13.

Duce, R.A., Liss, P.S., Merrill, J.T., Atlas, E.L., Buat-Menard, P., Hicks, B.B., Miller, J.M., Prospero, J.M., Arimoto, R., Church, T.M., Ellis, W., Galloway, J.N., Hansen, L., Jickells, T.D., Knap, A.H., Reinhadt, K.H., Schneider, E., Soudine, A., Tokos, J.J., Tsunogai, S., Wollast, R., Zhou, M., 1991. The atmospheric input of trace species to the world ocean. Global Biogeochem. Cycles 5, 193-259.

Elderfield, H., Schlutz, A., 1996. Mid-ocean ridge hydrothermal fluxes and the chemical composition of the ocean. Ann. Rev. Earth Planet. Sci. 24, 191-224.

Elrod, V.A., Berelson, W.M., Coale, K.H., Johnson, K.S., 2004. The flux of iron from continental shelf sediments: a missing source for global budgets. Geophys. Res. Lett. 31, L12307. doi:10.1029/2004GL020216.

Fung, I.Y., Meyn, S.K., Tegan, I., Doney, S.C., John, J.G., Bishop, J.K.B., 2000. Iron supply and demand in the upper ocean. Global Biogeochem. Cycles 14, 281-295.

Garrels, R.M., Mackenzie, F.T., 1971. Evolution of Sedimentary Rocks. Norton, New York.

Gordon, R.M., Coale, K.H., Johnson, K.S., 1997. Iron distributions in the Equatorial Pacific: implications for new production. Limnol. Oceanogr. 42, 419-431.

Greenland, D.J., Oades, J.M., Sherwin, T.W., 1968. Electron-microscope observations of iron oxides in red soils. J. Soil Sci. 19, 123-126.

Gurnell, A.M., 1987. Suspended sediment. In: Gurnell, A.M., Clarke, M.J. (Eds.), Glacio-Fluvial Sediment Transfer. Wiley, Chichester, pp. 305-354.

Haese, R.R., 2000. The reactivity of iron. In: Zabel, M. (Ed.), Marine Geochemistry. Springer-Verlag, Berlin, pp. 233-261.

Hallet, B., Hunter, L., Bogen, J., 1996. Rates of erosion and sediment evacuation by glaciers: a review of field data and their implications. Global Planet. Change 12, 213-235.
Hay, W.W., 1994. Pleistocene-Holocene fluxes are not the Earth's norm. In: Hay, W.W. (Ed.), Material Fluxes on the Surface of the Earth. National Academy Press, Washington, pp. 15-27.

Hay, W.W., 1998. Detrital sediment fluxes from continents to oceans. Chem. Geol. 145, 287-323.

Hedges, J.I., Keil, R.G., 1995. Sedimentary organic matter preservation: an assessment and speculative synthesis. Mar. Chem. 49, 81-115.

Hogg, R., Healy, T.W., Fuerstenau, D.W., 1966. Mutual coagulation of colloidal dispersions. Trans. Faraday Soc. 62, 1638-1651.

Holland, H.D., 1978. The Chemistry of the Atmosphere and Oceans. Wiley, New York.

Holliday, L.M., Liss, P.S., 1976. The behaviour of dissolved iron, manganese and zinc in the Beaulieu Estuary S. England. Estuar. Coastal Mar. Sci. 4, 349-353.

Horowitz, A.J., Elrick, K.A., 1987. The relation of stream sediment surface area, grain size and composition to trace element chemistry. Appl. Geochem. 2, 437-451.

Horowitz, A.J., Elrick, K.A., Smith, J.J., 2001. Estimating suspended sediment and trace element fluxes in large river basins: methodological considerations as applied to the NASQAN programme. Hydrol. Process. 15, 1107-1132.

Hutchins, D.A., DiTuuio, G.R., Zhang, Y., Bruland, K.W., 1998. An iron limitation mosaic in the California upwelling regime. Limnol. Oceanogr. 43, 1037-1054.

Israelachvili, J.N., 1992. Intermolecular and Surface Forces. Academic Press, London.

Janney, D.E., Cowley, J.M., Buseck, P.R., 2000. Transmission electron microscopy of synthetic 2- and 6-line ferrihydrite. Clays Clay Miner. 48, 111-119.

Jickells, T.D., Spokes, L.J., 2001. Atmospheric iron inputs to the ocean. In: Turner, D.R., Hunter, K.A. (Eds.), The Biogeochemistry of Iron in Seawate. Wiley, New York, pp. 85-121.

Johnson, K.S., Coale, K.H., Elrod, V.A., Tindale, N.W., 1994. Iron photochemistry in seawater from the equatorial Pacific. Mar. Chem. 46, 319-334.

Johnson, K.S., Chavez, F.P., Friederich, G.E., 1999. Continental-shelf sediment as a primary source of iron for coastal phytoplankton. Nature 398, 697-700.

Jones, I.W., Munhoven, G., Tranter, M., Huybrechts, P., Sharp, M.J., 2002. Modelled glacial and non-glacial $\mathrm{HCO}_{3}{ }^{-}, \mathrm{Si}$ and $\mathrm{Ge}$ fluxes since the LGM: little potential for impact on atmospheric $\mathrm{CO}_{2}$ concentrations and the marine Ge:Si ratio. Global Planet. Change 33, 139-153.

Kaiser, K., Guggenberger, G., 2000. The role of DOM sorption to mineral surfaces in the preservation of organic matter in soils. Org. Geochem. 31, 711-723.

Krupp, H., 1967. Particle adhesion, theory and experiment. Adv. Colloid Interface Sci. 1, 79-110.

Langmuir, D., 1997. Aqueous Environmental Geochemistry. Prentice Hall, New Jersey.

Lisitzin, A.P., 1972. Sedimentation in the Worlds Oceans. Soc. Econ. Paleont. Mineral., Tulsa, Oklahoma.

Lisitzin, A.P., 2002. Sea-Ice and Iceberg Sedimentation in the Ocean. Recent and Past. Springer-Verlag, Berlin.

Loscher, B.M., de Jong, J.T.M., de Baar, H.J.W., Veth, C., Dehairs, F., 1997. The distribution of iron in the Antarctic Circumpolar Current. Deep-Sea Res. II 44, 143-187.

Lyons, W.B., Nezar, C.A., Carey, A.E., Hicks, D.M., 2002. Organic carbon fluxes to the ocean from high-standing islands. Geology $\mathbf{3 0}$, $334-446$.

Mackey, D.J., O'Sullivan, J.E., Watson, R.J., 2002. Iron in the western Pacific: a riverine or hydrothermal source for iron in the Equatorial Undercurrent. Deep-Sea Res. 40, 877-893.

Maher, R.A., Dennis, P.F., 2001. Evidence against dust-mediated control of glacial-interglacial changes in atmospheric $\mathrm{CO}_{2}$. Nature 411, 176 180.

Martin, J.H., 1990. Glacial-interglacial $\mathrm{CO}_{2}$ change: the iron hypothesis. Paleoceanography 5, 1-11. 
Martin, J.H., Gordon, R.M., Fitzwater, S.E., 1990. Iron in Antarctic waters. Nature 345, 156-158.

Martin, J.M., Windom, H.L., 1991. Present and future roles of ocean margins in regulating marine biogeochemical cycles. In: Mantoura, R.F.C., Martin, J.M.R., Wollast, R. (Eds.), Ocean Margin Processes in Global Change. Wiley, New York, pp. 45-67.

Matijevic, E., 1980. Colloidal chemical aspects of the corrosion of metals. Pure Appl. Chem. 52, 1179-1193.

Mayer, L.M., 1999. Extent of coverage of mineral surfaces by organic matter in marine sediments. Geochim. Cosmochim. Acta 63, 207-215.

Maynard, J.B., 1976. The long-term buffering of the oceans. Geochim. Cosmochim. Acta 40, 1523-1532.

McManus, J., Berelson, W.M., Coale, K.H., Kilgore, T.E., 1997. Phosphorus regeneration in continental margin sediments. Geochim. Cosmochim. Acta 61, 2891-2907.

Miller, W.L., King, D.W., Lin, J., Kester, D.R., 1995. Photochemical redox cycling of iron in coastal seawater. Mar. Chem. 50, 63-77.

Millero, F.J., 2001. The Physical Chemistry of Natural Waters. WileyInterscience, New York.

Milliman, J.D., Syvitski, J.P.M., 1992. Geomorphic/tectonic control of sediment discharge to the ocean: the importance of small mountainous rivers. J. Geol. 100, 525-544.

Milliman, J.D., Farnsworth, K.L., Albertin, C.S., 1999. Flux and fate of fluvial sediments leaving large islands in the East Indies. J. Sea Res. 41, 97-107.

Moffett, J.W., 2001. Transformations among different forms of iron in the ocean. In: Turner, D.R., Hunter, K.A. (Eds.), The Biogeochemistry of Iron in Seawater. Wiley, New York, pp. 343-372.

Moore, R.M., Burton, J.D., Williams, P.J.LE.B., Young, M., 1979. The behaviour of dissolved organic material, iron and manganese in estuarine mixing. Geochim. Cosmochim. Acta 43, 919-926.

Moore, W.S., Wilson, A.M., 2005. Advective flow through the upper continental shelf driven by storms, buoyancy and submarine groundwater discharge. Earth Planet. Sci. Lett. 235, 564-576.

Paterson, W.S.B., 1994. The Physics of Glaciers. Pergamon, Oxford.

Petit, J.-R., Briat, M., Royer, A., 1981. Ice age aerosol content from East Antarctica ice core samples and past wind strength. Nature 293, 391-394.

Postma, D., Brockenhuus-Schack, B.S., 1987. Diagenesis of iron in proglacial sand deposits of late- and post-Weichselian age. J. Sediment. Petrol. 57, 1040-1053.

Poulton, S.W., Canfield, D.E., 2005. Development of a sequential extraction procedure for iron: implications for iron partitioning in continentally derived particulates. Chem. Geol. 214, 209-221.

Poulton, S.W., Raiswell, R., 2002. The low-temperature geochemical cycle of iron: from continental fluxes to marine sediment deposition. Am. $J$. Sci. 302, 774-805.

Poulton, S.W., Raiswell, R., 2005. Chemical and physical characteristics of iron oxides in riverine and glacial meltwater sediments. Chem. Geol. 218, 203-221.

Raiswell, R., 1984. Chemical models of solute acquisition in glacial meltwaters. J. Glaciol. 30, 49-57.

Raiswell, R., Anderson, T.F., 2005. Reactive iron enrichment in sediments deposited beneath euxinic bottom waters: constraints on supply by shelf recycling. In: McDonald, I., Boyce, A.J., Butler, I., Herrington, R.J., Polya, D. (Eds.), Mineral Deposits and Earth Evolution. Geol. Soc. London Spec. Publ. No. 218, pp. 179-194.

Raiswell, R., Canfield, D.E., 1998. Sources of iron for pyrite formation in marine sediments. Am. J. Sci. 298, 219-245.

Raiswell, R., Canfield, D.E., Berner, R.A., 1994. A comparison of iron extraction methods for the determination of degree of pyritization and the recognition of iron-limited pyrite formation. Chem. Geol. 111, $101-110$.

Ransom, B., Bennett, R.H., Baerwald, R., Shea, K., 1997. TEM study of in situ organic matter on continental margins: occurrence and the 'monolayer' hypothesis. Mar. Geol. 138, 1-9.
Rich, H.W., Morel, F.M.M., 1990. Availability of well-defined iron colloids to the marine diatom Thalassiosira weissflogii. Limnol. Oceanogr. 35, 652-662.

Schwertmann, U., Fischer, W.R., 1973. Natural amorphous ferric hydroxide. Geoderma 10, 237-247.

Schwertmann, U., Taylor, R.M., 1972. The transformation of lepidocrocite to goethite. Clays Clay Miner. 20, 151-158.

Shaw, S., Benning, L.G., Terrill, N.J., Davidson, L., 2004. Nucleation and growth of iron oxyhydroxide nanoparticles from solution: an in situ time-resolved Small Angle Scattering (SAXS) study. Geochim. Cosmochim. Acta 58, A158.

Shaw, S., Pepper, S.E., Bryan, N.D., Livens, F.R., 2005. The kinetics and mechanisms of the transformation of 2-line ferrihydrite to goethite and hematite under alkaline conditions, and in the presence of phosphate. Am. Mineral. 90, 1852-1860.

Sholkovitz, E.R., 1976. Flocculation of dissolved organic and inorganic matter during the mixing of river water and seawater. Geochim. Cosmochim. Acta 40, 831-845.

Sholkovitz, E.R., Elderfield, H.E., Szymczak, R., Casey, K., 1999. Island weathering: river sources of rare earth elements to the Western Pacific Ocean. Mar. Chem. 68, 39-57.

Slomp, C.P., Van Cappellen, P., 2004. Nutrient inputs to the coastal ocean through submarine groundwater discharge: controls and potential impact. J. Hydrol. 295, 64-86.

Souchez, R.A., Lorrain, R.D., Lemmens, M.M., 1973. Refreezing of interstitial water in a subglacial cavity of an alpine glacier as indicated by the chemical composition of ice. J. Glaciol. 66, 453-458.

Sposito, G., 1989. The Chemistry of Soils. Oxford University Press, New York.

Stumm, W., 1992. Chemistry of the Solid-Water Interface. WileyInterscience, New York.

Sugden, D.E., John, B.S., 1976. Glaciers and Landscape. Arnold, London.

Sunda, W.G., 2001. Bioavailability and bioaccumulation of iron in the sea. In: Turner, D.R., Hunter, K.A. (Eds.), The Biogeochemistry of Iron in Seawater. Wiley, New York, pp. 41-84.

Syvitski, J.P.M., Burrell, D.C., Skei, J.M., 1987. Fjords. Springer-Verlag, Berlin.

Taniguchi, M., Burnett, W.C., Cable, J.E., Turner, J.V., 2002. Investigation of submarine groundwater discharge. Hydrol. Process. 16, 2115-2129.

Tipping, E., 1981. The adsorption of aquatic humic substances by iron oxides. Geochim. Cosmochim. Acta 45, 191-199.

Tipping, E., Cooke, D., 1982. The effects of adsorbed humic substances on the surface charge of goethite $(\alpha-\mathrm{FeOOH})$ in freshwaters. Geochim. Cosmochim. Acta 46, 75-80.

Tipping, E., Woof, C., Cooke, D., 1981. Iron oxide from a seasonally anoxic lake. Geochim. Cosmochim. Acta 45, 1411-1419.

Tranter, M., 2005. Sediment and solute transport in glacial meltwater streams. In: Anderson, M.G. (Ed.), Encyclopedia of Hydrological Sciences, vol. 169, Wiley, New York, pp. 2633-2645.

Tranter, M., Huybrechts, P., Munhoven, G., Sharp, M.J., Brown, G.H., Jones, I.W., Hodson, A.J., Hodgkins, R., Wadham, J.L., 2002. Glacial bicarbonate, sulphate and base cation fluxes during the last glacial cycle, and their potential impact on atmospheric $\mathrm{CO}_{2}$. Chem. Geol. 190, 33-44.

Turner, A., Millward, G.E., Morris, A.W., 1991. Particulate metals in five major North Sea estuaries. Estuar. Coastal Shelf Sci. 32, 325-346.

Van Olphen, H., 1963. Clay Colloid Chemistry. Wiley Interscience, New York.

Warrick, R., Oerlemans, J., 1990. Sea level rise. In: Houghton, J.T., Jenkins, G.J., Ephraums, J.J. (Eds.), Climate Change. The IPCC Scientific Assessment. Cambridge University Press, Cambridge, pp. 257-281.

Watson, A.J., 2001. Iron limitation in the oceans. In: Turner, D.R., Hunter, K.A. (Eds.), The Biogeochemistry of iron in Seawater. Wiley, New York, pp. 9-39.

Watson, A.J., Bakker, D.C.E., Ridgwell, A.J., Boyd, P.W., Law, C.S., 2000. Effect of iron supply on Southern Ocean $\mathrm{CO}_{2}$ uptake and implications for glacial atmospheric $\mathrm{CO}_{2}$. Nature 407, 730-733. 
Waychunas, G.A., 2001. Structure, aggregation and characterization of nanoparticles. Reviews of Mineralogy and Geochemistry 44, 105-166.

Wells, M.L., Mayer, L.M., 1991. The photoconversion of colloidal iron oxyhydroxides in seawater. Deep-Sea Res. 38, 1379-1395.

Wells, M.L., Zorkin, N.G., Lewis, A.G., 1983. The role of colloid chemistry in providing a source of iron to phytoplankton. J. Mar. Res 41, 731-746.

Wen, L.S., Santschi, P., Gill, G., Paternostro, C., 1999. Estuarine trace metal distributions in Galveston Bay: importance of colloidal forms in the speciation of the dissolved phases. Mar. Chem. 63, 185-212.

Whitney, P.R., 1975. Relationship of manganese-iron oxides and associated heavy metals to grain size in stream sediments. J. Geochem. Explor. 4, 251-263.
Wolery, T.J., Sleep, N.H., 1976. Hydrothermal circulation and geothermal flux at mid-ocean ridges. J. Geol. 84, 249-275.

Wollast, R., Mackenzie, F.T., 1983. The global cycle of silica. In: Aston, S.R. (Ed.), Silicon Geochemistry and Biogeochemistry. Academic Press, London, pp. 39-76.

Wilson, R.C.L., Drury, S.A., Chapman, J.L., 2000. The Great Ice Age: Climate Change and Life. Routledge, London.

Wu, J., Luther III, G.W., 1996. Spatial and temporal distribution of iron in the surface water of the northwestern Atlantic Ocean. Geochim. Cosmochim. Acta 60, 2729-2742.

Yee, N., Shaw, S., Benning, L.G., Nguyen, T.H., 2006. The rate of ferrihydrite transformation to goethite via the Fe II pathway. Am. Mineral. 91, 92-96. 